\title{
El «otro príncipe»: piedad y carisma de Fernando el Católico en su entorno cortesano'
}

\author{
The «other prince»: Piety and Charism of \\ Fernando the Catholic in his Courtly Milieu
}

\author{
Álvaro FERNÁNDEZ DE CÓRDOVA MIRALLES \\ Universidad de Navarra \\ afdecordova@unav.es
}

\begin{abstract}
On the occasion of the 5 th centenary of Ferdinand the Catholic (1516-2016) this paper addresses a lesser known facet of his personality, and most representative of his policy - his religiosity. The paper attempts to reconstruct the fernandian charism through its religious models, ideals of perfection, moral literature and spiritual currents which shaped the docta pietas of the environment. In this framework of ideas and people we analyze the liturgical and devotional activity of the Catholic King, developed under the impulse of a more internalized piety, particularly cognizant of the Passion of Christ, which had unprecedented consequences in the court's welfare activity.
\end{abstract}

Keywords: Ferdinand II of Aragon and V of Castile; Catholic Kings; religiosity; charisma; devotions; royal representation; ceremonies.
Resumen: A la sombra del $v$ Centenario de Fernando el Católico (1516-2016) el presente trabajo aborda una de las facetas menos conocidas de su personalidad, y más representativas de su política: su religiosidad. Para ello hemos reconstruido el carisma fernandino a través de sus modelos religiosos, los ideales de perfección, la literatura moral y las corrientes espirituales que configuraron la docta pietas de su entorno. En este entramado de ideas y personas se indaga en la actividad litúrgica y devocional del rey Católico, desarrollada bajo el impulso de una piedad más interiorizada, especialmente sensible a la Pasión de Cristo, que tuvo inéditas consecuencias en la actividad asistencial cortesana.

Palabras clave: Fernando II de Aragón y v de Castilla; Reyes Católicos; religiosidad; carisma; devociones; representación regia; ceremonias.

\section{SILENCIOS Y DESTELLOS DE UN CENTENARIO (1516-2016)}

Por mucho que el título de Católico acompañe desde 1496 el nombre de Fernando II de Aragón y V de Castilla, no es mucho lo que se ha escrito sobre la religiosidad de un monarca habitualmente contemplado desde el ángulo político. La

1 Este trabajo forma parte del proyecto de investigación Las formas de representación del poder en la Península Ibérica bajomedieval: ceremonias, juramentos y divisas (HAR2014-58542-P), aprobado y financiado por el Ministerio de Economía y Competitividad. 
innegable vitalidad religiosa de su esposa Isabel quizá haya propiciado esta inercia historiográfica que, desde Baltasar Gracián, ha relegado a Fernando a la esfera del pragmatismo político bajo la sombra demasiado alargada de Nicolás Maquiavelo. Sin embargo, mal se comprenderá aquel reinado caracterizado por la unidad de los dos cónyuges, si se escuchara la voz del rey con menor intensidad que la de su consorte, aunque aún queden por identificar los perfiles espirituales de aquel príncipe aragonés que fue el más interesado en lograr del papado el título que selló su recuerdo póstumo.

El v Centenario fernandino (1516-2016) se ha presentado como una excelente ocasión para impulsar su historiografía algo más rezagada que la isabelina, desde los pioneros trabajos de Jaime Vicens Vives a los más recientes de Ángel Sesma Muñoz, Luis Suárez Fernández, Ernest Belenguer o Miguel Ángel Ladero Quesada ${ }^{2}$. Partiendo de esta valiosa base, se han sumado investigaciones sobre la estructura política, la evolución socio-económica, o el desarrollo cultural y religioso de aquel reinado medular en la configuración de la monarquía hispánica. De ahí que fueran altas las expectativas ante el nuevo aniversario que llegó a proponerse como Acontecimiento de Especial Interés Público, con la esperanza de contar con una cobertura institucional tan amplia como la del Centenario de la reina (1504-2004).

El gobierno de Aragón y la Universidad de Zaragoza tomaron la iniciativa al organizar una serie de exposiciones y reuniones científicas que cristalizaron en dos excelentes publicaciones. Nos referimos al congreso sobre La imagen de Fernando el Católico en la Historia, la Literatura y el Arte, celebrado en la Universidad Zaragoza en el 2014 para abordar la evolución propagandística, literaria, historiográfica y artística del icono fernandino, desde la interdisciplinariedad propuesta por sus coordinadores Aurora Egido y José Enrique Laplana ${ }^{3}$. Un año después, coincidiendo con el año del Centenario, se celebró en el palacio de la Aljafería la magnífica exposición El rey que imaginó España y la abrió a Europa, bajo la dirección de José Ángel Sesma y Carmen Morte 4 . Las 150 piezas allí reunidas pretendían recrear la vida del monarca en una constelación de esferas que

2 Véase el recorrido historiográfico ofrecido por Ernest BELENGUER CEBRIÀ, Balance historiográfico sobre Fernando II de Aragón, en Ricardo Centellas Salamero (coord.), Ferdinandus Rex Hispaniarum: príncipe del renacimiento, Zaragoza, 2006, pp. 17-32.

3 Aurora EgIDO y José Enrique LAPLANA (eds.), La imagen de Fernando el Católico en la Historia, la Literatura y el Arte, Zaragoza, 2014.

4 M. Carmen MorTe García, y José Ángel Sesma MuÑoz (coords.), Fernando II de Aragón. El rey que imaginó España y la abrió a Europa, Zaragoza, 2015. 
enlazaban con el legado imperial de Carlos V. Otras ciudades como Plasencia, San Sebastián de los Reyes o Granada, se sumaron a la conmemoración con exposiciones de carácter local que mostraban la integración del territorio en los proyectos de la monarquía.

Entre las jornadas académicas, hay que destacar las organizadas por La Universidad de Extremadura y el Ayuntamiento de Madrigalejo, sobre los mitos, actividad bélica, y el contexto extremeño del reinado ${ }^{5}$. A estas reuniones científicas se sumaron los ciclos de conferencias organizadas por la fundación zaragozana Manuel Giménez Abad, la universidad de Granada, y en Madrid la Fundación Rafael del Pino, la Fundación Universitaria Española, la Real Academia de Ciencias Morales y Políticas, y el Centro de Estudios Políticos y Constitucionales. Mayor dimensión tuvo el Congreso Internacional organizado en la Universidad de Salamanca sobre la Modernidad de España, borizonte europeo y apertura americana, que dedicaba algunos paneles a rescatar el legado del rey Católico en estos procesos culturales y políticos.

El panorama historiográfico también se ha enriquecido por algunas síntesis interpretativas, como la reciente biografía de Henry Kamen, que plantea un recorrido vital del monarca para acabar con su «mito histórico» y ponderar su huella en la España moderna ${ }^{6}$. Desde una perspectiva política, Rus Rufino ha elaborado una biografía que celebra la capacidad del soberano de integrar territorios respetando leyes e instituciones, y de ofrecer ambiciosos proyectos de colaboración y acción internacional ${ }^{7}$. Finalmente, a Fernando Martínez Laínez debemos una divulgativa crónica del reinado, dotada de tensión dramática y admiración por el biografiado $^{8}$.

Por su valor documental es preciso mencionar el estudio y edición de los dos últimos testamentos del rey -el firmado en Aranda de Duero el 26 de abril de 1515 y el de Madrigalejo del 22 de enero de 1516- que han llevado a cabo José Manuel Calderón Ortega y Francisco Javier Díaz González'; sin olvidar el valioso repertorio iconográfico de Marta Serrano Coll, que completa el antiguo trabajo

\footnotetext{
Antonio-Miguel Bernal (ed.), Fernando el Católico, rey, Madrid, 2016.

6 Henry Arthur Francis KAMEN, Fernando el Católico, 1451-1516. Vida y mitos de uno de los fundadores de la España moderna, Madrid, 2015.

7 Salvador RUS RUFINO, Una biografía política de Fernando el Católico, la constitución de una monarquía universal, V centenario de su muerte 1516-2016, Madrid, 2016.

8 Fernando Martínez LaÍNEZ, Fernando el Católico: crónica de un reinado, Madrid, 2015.

9 José Manuel CALDERÓN ORTEGA, y Francisco Javier DÍAZ GONZÁLEZ, El proceso de redacción del último testamento de Fernando el Católico el 22 de enero de 1516, Zaragoza, 2015.
} 
de Pardo Canalis ${ }^{10}$. Finalmente, la aportación más novedosa ha sido la monografía de Miguel Ángel Ladero Quesada sobre la gobernación castellana del rey Católico, el período más desconocido y no menos innovador que adquiere ahora una nueva entidad ${ }^{11}$.

A la vista de estas iniciativas sorprende la desigual celebración de un Centenario atendido exclusivamente por el mundo académico y algunas instituciones locales. La prensa nacional ha lamentado el inexplicable silencio de las organizaciones públicas teniendo en cuenta la importancia histórica de un reinado que supone el «arranque de una historia compartida», canalizada a través de la monarquía y fundamentada en una gran herencia patrimonial puesta al servicio de una acción exterior común en Europa, Asia, norte de África y Nuevo Mundo ${ }^{12}$. Un abigarrado tapiz, grávido de consecuencias históricas, y tejido por ineludibles hebras religiosas que impulsaron y legitimaron buena parte de sus proyectos.

Anuario de Historia de la Iglesia no ha querido dejar pasar esta oportunidad para ofrecer una serie de reflexiones sobre las encrucijadas políticas y espirituales suscitadas en este reinado decisivo. Para ello hemos dividido el cuaderno en dos grandes bloques. El primero aborda las principales empresas influidas en mayor o menor medida por móviles religiosos: la defensa del Mediterráneo ante el avance otomano, la percepción de la cuestión judía, la reforma de las órdenes religiosas y la implicación regia en las elecciones episcopales, sin olvidar una reflexión especial sobre la figura del rey con motivo de uno de los momentos más dramáticos de su vida. El segundo bloque ahonda en el ambiente áulico que alimentó estos proyectos y que está siendo objeto de recientes y sugestivas investigaciones: la espiritualidad cortesana, la organización de los servicios religiosos y la literatura devocional generada a la sombra de la monarquía. Pretendemos unir así tres esferas que permitirán comprender la dimensión religiosa del reinado: la vida del soberano, el clima espiritual palatino y su proyección sobre la Iglesia del reino. El conocimiento de estas complejas dinámicas constituye todo un reto historiográfico que merece la pena afrontar para poder explicar las inéditas sinergias entre piedad y poder que se dieron en este momento histórico que alumbró el mundo moderno. Esperamos que estas páginas hayan contribuido a ello.

10 Marta Serrano Coll, Ferdinandis Dei gracia Rex Aragonum, la efigie de Fernando II el Católico en la iconografía medieval, Zaragoza, 2014.

11 Miguel Ángel Ladero Quesada, Los últimos años de Fernando el Católico, 1505-1517, Madrid, 2016.

12 Joaquim Coll, Olvidado Rey Católico, en El País, 3 septiembre 2016. 


\section{TRAYECTORIA DE UN CARISMA}

Contra lo que pueda esperarse, el análisis de la religiosidad de los príncipes no ha sido un campo específicamente tratado por la historiografía española hasta las últimas décadas, en que ha sido rescatada esta faceta para comprender los fenómenos de construcción monárquica, la representación regia o determinados proyectos políticos o eclesiásticos ${ }^{13}$. Por las razones apuntadas, la figura de Fernando el Católico no ha sido ajena a esta dinámica, aunque algunos aspectos de su religiosidad salgan a relucir en los estudios sobre su ejercicio del poder, el entorno cortesano o las actividades de mecenazgo artístico o cultural. Sobre esta base intentaremos reconstruir los modelos religiosos asumidos por el rey a raíz de los desafíos y las políticas emprendidas; una trayectoria iconológica en la que confluyen las categorías representativas medievales que emergieron con especial intensidad en este período, y evolucionaron al compás del relato historiográfico, la propagada cortesana, las corrientes espirituales del momento y la piedad personal del soberano. Y aunque la conciencia regia siempre será uno de los territorios más inaccesibles para el historiador, no lo son sus huellas documentales que nos permitirán reconstruir el perfil religioso -intenso y cambiante- del carismático rey Católico, que fue capaz de catalizar los fermentos religiosos de la dinastía Trastámara y proyectarlos a la Modernidad.

\section{a) Un rey elegido en el paroxismo político (1469-1479)}

Los trabajos de Alain Milhou, Eulàlia Duran Grau o Joan Requesens han mostrado el vigor de las profecías monárquicas que imperaban en la corte aragonesa a fines del siglo XV y alimentaron las esperanzas del heredero de Juan II en uno de los momentos más críticos de la monarquía. Con sólo trece años y en plena sublevación catalana, fue exhortado a cultivar la humildad y otras virtudes para revindicar su «majestad sagrada» y castigar a los rebeldes que habían aban-

13 Sin pretensiones de exhaustividad véanse las aportaciones de José Manuel NIETO SoRIA, Iglesia y génesis del Estado moderno en Castilla: (1369-1480), Madrid, 1994. David Nogales RinCón, La representación religiosa de la monarquía castellano-leonesa: la capilla real (1252-1504), Madrid, 2009. César OlIVERA SERRANO, Devociones regias y proyectos políticos: los comienzos del monasterio de San Benito el Real de Valladolid (1390-1430), en Anuario de estudios medievales, 43/2 (2013), pp. 799832; ID., Felipa y Catalina de Láncaster: Religiosidad y relato historiográfico, en Anuario de estudios medievales, 46/1 (2016), pp. 361-391. 
donado «la fe crestiana» ${ }^{14}$. Y si sus enemigos alegaban la fama de santidad de su hermanastro Carlos de Viana, fallecido en extrañas circunstancias (1461), los fernandinos activaron las profecías celebrando su entrada en Barcelona (1472) como nuevo rey mesiánico, mientras Alfonso de Jaén lo elevaba a emperador de los últimos tiempos que destruiría a los musulmanes, conquistaría Jerusalén, y alcanzaría la unidad de la fe bajo una monarquía universa ${ }^{15}$. En este contexto se entiende su representación alegórica en el relieve en mármol conservado en Londres que representa al joven príncipe entre Marte y Mercurio con correlaciones astrales de su prometedor reinado ${ }^{16}$.

El conflicto sucesorio castellano (1474-1479) también activó el profetismo isidoriano que convertía a Fernando -casado con la heredera Isabel- en el restaurador de la unidad hispano-visigótica, como afirmaba Diego de Valera en 1476 frente a los que consideraban a Alfonso V de Portugal el esperado rey Encubierto ${ }^{17}$. Fray Íñigo de Mendoza dio un nuevo paso al transformar este antiguo profetismo trastámara en un mesianismo exaltador que hacía de Fernando un elegido de Dios llamado a salvar al reino enfermo, con el yugo de Cristo representado en su divisa ${ }^{18}$. De ahí que la victoria de Toro (1476) se interpretara como la confirmación divina de su misión unificadora, que añadía a la integración castellano-aragonesa el reino lusitano que recompondría la antigua unidad visigoda. Tales expectativas tuvieron una importante dimensión litúrgica en la partida de Valladolid a la campaña militar (1475), la conmemoración de la victoria en Toledo $(1477)^{19}$, o en las visitas al monasterio de Guadalupe (1477-1479) que enlazaban con la tradición

14 Martín de RiQuer, Història de la literatura catalana, vol. III, Barcelona, 1964, p. 142.

15 Alain MiLHOU, Colón y su mentalidad mesiánica en el ambiente franciscanista español, Valladolid, 1983. Eulàlia Duran GRAU, y Joan REQUESENS, Profecia i poder al renaixement: text profétics catalans favorables a Ferran el Catòlic, Valencia, 1997, pp. 299-325. Isabelle RousSEAU-JACOB, Bibliothèque Nationale, Paris, en L'eschatologie royale de tradition joachimite dans la Couronne d'Aragon (XIII ${ }^{e}-X V^{e}$ siècle), París (Les Livres d'e-Spania «Sources», 6), [En línea], Publicado el 17 septiembre 2015, consultado el 7 abril 2017. URL: http://e-spanialivres.revues.org/936.

16 Carmen Morte García, La imagen de Fernando el Católico en el Arte: el tiempo vivido y el tiempo recreado (1452-1700), en EGIDO y LAPLANA (eds.), La imagen de Fernando el Católico... [ver n. 3], pp. 301-302.

17 Ana Isabel CARRASCO MANCHADO, Isabel I de Castilla y la sombra de la ilegitimidad: propaganda y representación en el conflicto sucesorio (1474-1482), Madrid, 2006, pp. 230-232 y 379 y ss.

18 Íñigo de Mendoza, Cancionero, ed. por Julio Rodríguez Puértolas, Madrid, 1968, pp. 299-318.

19 Más adelante comentaremos detalles de estas ceremonias que cuentan con interesantes antecedentes analizados por José Manuel NIETO SORIA, La victoria como espectáculo de los Trastámaras al comienzo de los Austrias, en Ana ARranz GuZMán, María del Pilar Rábade Obradó, y Oscar Villarroel GonZÁLEZ (coords.), Guerra y paz en la Edad Media, Madrid, 2013, pp. 497517. 
romera Trastámara ${ }^{20}$. Sea como fuere, no conviene exagerar el alcance de unas profecías desestimadas por colaboradores como Antonio Geraldini, que animaba al joven monarca a superar aquellos determinismos astrales con el cultivo de la virtud personal, sumándose al programa de superación moral que le proponían Gómez Manrique y fray Hernando de Talavera, como veremos más adelante ${ }^{21}$.

\section{b) Devoto cruzado a las puertas de Europa (1480-1492)}

El fin del conflicto sucesorio abrió un período de paz que permitió a Isabel y Fernando consolidar su posición con la celebración de las Cortes castellanas en Toledo (1480) y las aragonesas en Calatayud, Barcelona y Valencia (1481), con su correlato eclesiástico en las asambleas de Sevilla (1478) y Córdoba (1482). Comenzó entonces un proceso de defensa y consolidación de la unidad peninsular según una nueva concepción territorializada de la Cristiandad, y una comprensión de su integración europea que abandonaba la antigua ubicación angula mundi (concepción mitológica) por una nueva posición de vanguardia a las puertas de Europa (concepción cosmográfica) ${ }^{22}$. La responsabilidad asumida por los monarcas ante la cuestión otomana expresa este cambio de mentalidad que Nicasio Salvador Miguel detecta en los jóvenes príncipes antes de su acceso al trono, y de su intervención en la defensa de Rodas y Otranto (1480). La preocupación otomana situaba a los monarcas en el seno de una Cristiandad de la que se sentían responsables, abriendo un espacio de negociación con el papado que se consolidó durante la campaña de Granada (1481-1492).

La campaña contra el último reducto musulmán debió superar ciertos problemas de legitimidad, advertidos por Fernando al considerar «la guerra con los moros» como «voluntaria, e para ganar lo ageno», a diferencia de la campaña del Rosellón contra Francia, que «era neçesaria para recobrar lo suyo» ${ }^{23}$. Sin em-

20 Arturo Álvarez, Guadalupe, la devoción de los Reyes Católicos, en Historia 16, 80 (1982), pp. 83 89. Precedentes de esta devoción regia en Francisco de Paula CAÑAS GálVEZ, Devoción mariana y poder regio: las visitas reales al monasterio de Guadalupe durante los siglos XIV y XV (ca. 1330-1472), en Hispania sacra, 64 (2012), pp. 427-447.

21 Martin FrÜH, Profecía y realidad: una oda de Antonio Geraldini al rey Fernando el Católico, en De litteris neolatinis in America Meridionali, Portugallia, Hispania, Italia cultis, Valencia, 2002, pp. 47-67.

22 Tratamos este tema en La política europea de Fernando Hispaniae rex. Del despliegue diplomático a la integración atlántico-mediterránea (1474-1516), en MORTE GARCÍA, y SESMA MUÑOZ (coords.), Fernando II de Aragón... [ver n. 4], pp. 63-79.

23 Fernando de Pulgar, Crónica de los Reyes Católicos, ed. por J. de M. Carriazo, vol. II, Madrid, 1943, pp. 113-115. 
bargo, el empeño por liberar la tierra profanada reactivó el profetismo catalanoaragonés que anunciaba la conquista de Granada y el fin del Islam, como Pedro Marcuello vaticinó a Fernando en $1482^{24}$. También fue necesario justificar el uso de rentas eclesiásticas para sostener una campaña para «que la santa fe católica sea acrescentanda y la Cristiandad se quite de un tan continuo peligro como tiene aquí a las puertas», como el rey explicó al papa en $1485^{25}$. Fue tomando forma así la imagen de los monarcas como defensores de la Cristiandad con un singular reparto de funciones que asignaba el apoyo religioso a la reina (orator), y la dirección militar al rey (bellator) ${ }^{26}$. Fernando se presentaba entonces como el nuevo rey cruzado -opuesto al monarca codicioso de rentas- que ofrecía vida y fortuna para la defensa de la fe, lo que exigió militarizar su iconografía con la armadura vista en los relieves de la sillería de la catedral de Toledo (c. 1489-1496) o en el retablo proyectado para la iglesia San Juan de los Reyes (Toledo) ${ }^{27}$.

El perfil guerrero se complementó con una faceta devocional que recuperaba los perfiles religiosos de su abuelo Fernando, conquistador de Antequera (1410), o la de Juan II en la batalla de la Higueruela $(1431)^{28}$. En este contexto los cronistas describieron las celebraciones propiciatorias, combinando los actos militares -como el despliegue de banderas- con celebraciones litúrgicas, que Fernando podía modificar, como sucedió en la campaña de Loja al ordenar «retirar ceremoniosamente las banderas en aquella solemnidad, cuando era costumbre celebrar la procesión antes de la misa ${ }^{29}$.

24 Duran Grau, y Requesens, Profecia $i$ poder... [ver n. 15], pp. 385-403. Pedro Marcuello, Cancionero, ed. por J. M. Blecua, Zaragoza, 1987, p. 51.

25 José GoÑ GaZTAMBIDE, La Santa Sede y la reconquista del reino de Granada, en Hispania Sacra, 11 (1951), p. 27.

26 Sobre esta rica literatura cfr. Rafael G. PEINADo SANTAELla, «Christo pelea por sus castellanos»: el imaginario cristiano de la guerra de Granada, en José Antonio ALCANTUD, y Manuel BARRIOS AgUilera (ed.), Las tomas: antropología histórica de la ocupación territorial del reino de Granada, Granada, 2000, pp. 553-624. Véanse los trabajos de Teresa Jiménez Calvente, Nicasio Salvador Miguel y yo mismo en EGIDO y LAPLANA (eds.), La imagen de Fernando el Católico... [ver n. 3]. Y la investigación de Nicasio SALVADOR MIGUEL, La conquista de Málaga (1487). Repercusiones festivas y literarias en Roma, Santa Bárbara, 2014.

27 Joaquín YARZA LUACES, Isabel La Católica: promotora artística, León, 2005, p. 161. Dorothee HeIM, Instrumentos de propaganda política borgoñona al servicio de los Reyes Católicos: los relieves de la guerra de Granada en la sillería de la catedral de Toledo, en El intercambio artístico entre los reinos bispanos y las cortes europeas en la baja Edad Media, León, 2009, pp. 203-216.

28 Víctor MuÑoz GómEZ, De Medina del Campo a Zaragoza: un periplo por las devociones políticas de un principe castellano bajomedieval (el infante Fernando de Antequera, 1380-1416), en eHumanista. Fournal of Iberian Studies, 24 (2013), pp. 375-395. José Manuel NIETO SORIA, El ciclo ceremonial de la batalla de la Higueruela (1431), en Estudios de Historia de España, 12 (2010), pp. 389-404.

29 Alonso de Palencia, Guerra de Granada, Barcelona, 2017, p. 35. 
También se multiplicaron las peregrinaciones o romerías del regio matrimonio a determinados santuarios para impetrar el favor divino, apuntalando la imagen de Fernando como rey devoto asistido por la Providencia. Es el caso de la romería al santuario de Santa María de Daroca (Zaragoza) en 1482 para rezar ante la reliquia de los Sagrados Corporales -objeto del milagro eucarístico de 1231-, que se repitió seis años después con la donación fernandina de cinco lámparas para iluminar el altar de los Corporales $^{30}$, y el encargo del políptico que lo representa de rodillas con su esposa y sus hijos mayores ante el milagro eucarístico. El gesto se repetirá en Murcia al encargar su representación orante para el retablo de la iglesia de la Virgen de la Claustra, en plenos preparativos de la campaña ${ }^{31}$. Un valor simbólico especial tuvo la peregrinación a Santiago de Compostela (1486) para venerar las reliquias del Apóstol y solicitar su protección en la contienda, con la promesa de volver si se cumplía su voto y construir un nuevo hospital para la atención de los peregrinos ${ }^{32}$.

Desde el punto de vista litúrgico, las crónicas también describen las acciones de gracias por las victorias. Habitualmente se organizaba una procesión a la iglesia mayor o bajo la advocación de Santiago, como sucedió en Vizcaya al anunciarse la toma de Zahara (1481), decribiéndose la «solenpne proçesión» encabezada por el clero palatino y local junto a los reyes, seguidos por los grandes de corte hasta la iglesia mayor, donde se celebró una «misa muy solenpne, con canto de órgano y órganos» ${ }^{33}$. Un año después sucedió algo parecido en Medina del Campo al conocerse la toma de Alhama (1482): «Y levantándose de la mesa, él [el Rey] y la Reyna fueron a la iglesia de señor Santiago en la dicha villa a donde dieron muchas gracias y loores a nuestro Señor por la victoria y toma de Alhama, y los perlados y sacerdotes de su real capilla cantaron el himno Te Deum, y de allí vuelto a su palacio se partió el mesmo día para el Andaluzía y con él muchos caballeros que entonces estaban en la corte» ${ }^{34}$. Otras veces se alude a la plegaria del rey, como sucedió en Córdoba tras la entrega de Montefrío y Moclín (1486), en que éste «fue a fazer oración a la iglesia mayor e dar graçias

30 José Manuel Cruz Valdovinos, Platería en la época de los Reyes Católicos, Madrid, 1992, p. XXV.

31 Rodolfo Bosque CarCeller, Murcia y los Reyes Católicos, Murcia, 1953, pp. 90-95.

32 César Olivera SerRano, Notas sobre la peregrinación a Compostela de los Reyes Católicos en 1486, en Iacobvs, 21-22 (2006), pp. 349-362. Teresa JiMÉNEZ CALVENTE, Nebrija, poeta áulico: la Peregrinatio Regis et Reginae ad Sanctum Iacobum. Edición, traducción y estudio, en Medievalismo 20 (2010), pp. 63-95.

33 Historia de los hechos del Marqués de Cádiz, ed. por Juan Luis Carriazo Rubio, Granada, 2003, p. 230.

34 Lucio Marineo Sículo, Vida y hechos de los Reyes Católicos, Madrid, 1943, p. 108. 
e loores a Nuestro Señor e a la gloria Madre suya e al apóstol Santiago de las victorias avidas» ${ }^{35}$.

Especial solemnidad revistieron las tomas de posesión de las plazas conquistadas, donde se alzaban los tres pendones (cruzada, Santiago y pendón real), mientras el clero entonaba el himno Te Deum. Después de la consagración de la antigua mezquita -emplazada tantas veces sobre un templo cristiano-, el rey procesionaba con sus tropas «con gran pompa, entonando cánticos sagrados» como sucedió en Málaga (1487) o en Almería (1489) ${ }^{36}$. Fernando extendió estas plegarias a otras ciudades, suscitando sinergias espirituales que unificaba sus reinos o conectaban la empresa granadina con otros espacios europeos, incluida la Ciudad Eterna ${ }^{37}$. En casos especiales, como la caída de Granada (1492), Hernando de Talavera llegó a componer un oficio litúrgico que celebrara la victoria en el marco de la historia salutis, aplicando a Fernando el modelo del rey salvador que como un nuevo Josué (alter Iosue) rescata la tierra prometida del reino granadino, o como un nuevo Ciro (aliter Ciri) que libera al pueblo como el rey persa con los judíos esclavizados en Babilonia ${ }^{38}$.

Los perfiles guerreros del monarca se atenuaron con otros elementos de la tradición clásica y el cristianismo. Nos referimos a la misericordia practicada por el «clementísimo monarca» con los vencidos ${ }^{39}$, o la liberación de los cautivos por la que recibía el besamanos de los prisioneros en contextos a veces milagrosos ${ }^{40}$. La cristianización del territorio también hizo despuntar la figura del «rey evan-

35 Diego de Valera, Crónica de los Reyes Católicos, Madrid, 1927, p. 212.

36 Palencia, Guerra de Granada... [ver n. 29], p. 278. PUlGar, Crónica ... [ver n. 23], vol. II, pp. 334335. Véanse también los testimonios aportados por SALVADOR MigUEL, La conquista de Málaga... [ver n. 26], pp. 32-34

37 Véanse las cartas enviadas a Burgos por la toma de Loja (1486); PeInAdo SaNTAELLA, «Christo pelea por sus castellanos»... [ver n. 26], p. 464. Para la correspondencia europea cfr. Álvaro FERNÁNDEZ DE CÓRDOVA Miralles, Imagen de los Reyes Católicos en la Roma pontificia, en En la España Medieval, 28 (2005), pp. 345-349. Raúl GONZÁLEZ ARÉVALO, La guerra di Granada nelle fonti fiorentine, en Archivio storico italiano, 164/2 (2006), pp. 387-418; ID., Ecos de la toma de Granada en Italia: de nuevo sobre las cartas a Milán y Luca, en Homenaje al profesor Eloy Benito Ruano, vol. I, Murcia, 2010, pp. 343-353.

38 Francisco Javier MARTÍNEZ MEDINA, Las teorías religiosas del poder político en la España de los Reyes Católicos, en Oficio de la toma de Granada, Granada, 2003, pp. 11-42.

39 PALENCIA, Guerra de Granada... [ver n. 29], p. 286.

40 Pulgar, Crónica... [ver n. 23], vol. II, pp. 49 y ss. Pedro Manuel Cátedra, La historiografía en verso en la época de los Reyes Católicos. Juan Barba y su «Consolatoria de Castilla», Salamanca, p. 268. M Eugenia DÍAZ TENA, Los Reyes Católicos y la redención de cautivos en un milagro mariano de finales del siglo XV(I), en Natalia FERnándeZ RodríGuEZ, y María FERnándeZ FERreiro (coords.), Literatura medieval y renacentista en España: líneas y pautas, Salamanca, 2012, pp. 499506. 
gelizador» que se consolidó años después con los descubrimientos atlánticos ${ }^{41}$; mientras su perfil caritativo y reformador se expresaba con la creación de hospitales castrenses y la renovación moral de las tropas, prohibiendo la prostitución o los juegos de azar, e intensificando la actividad pastoral en los campamentos hasta convertir a aquel «ejército de soldados» en una «congregación de religiosos», como afirmó Bernardino López de Carvajal en $1490^{42}$.

La acción ad extra contra el islam granadino y otomano tuvo su repercusión ab intra de sus reinos, con un movimiento de purificación religiosa que desencadenó la expulsión de los judíos reacios a convertirse. Como predicador y confesor real, Martín García constituye un testigo de excepción para comprender la visión de la cuestión judía en el entorno fernandino ${ }^{43}$. Nadie mejor que Manuel Montoza Coca, especialista en este culto teólogo, para abordar el tema a través de sus sermones a la comunidad conversa para lograr su sincera conversión y corregir las malas costumbres de la población cristiana. Sin minimizar los componentes de hostilidad hacia la comunidad hebrea, el predicador comparte la eclesiología paulina que convoca a conversos y cristianos viejos a un único pueblo de Dios, sin barreras étnicas ${ }^{44}$. De ahí que García adopte una cierta indulgencia para persuadir e integrar a las minorías religiosas, exhortando al mismo tiempo al rey a imponer la paz en la ciudad y «reduzcáis a la fe de Cristo a los agarenos que en ella viven $[. .$.$] como dispersasteis a los herejes y judíos».$

En este contexto triunfalista el atentado a Fernando en Barcelona (1492) provocó un impacto emocional documentado en la cronística y la literaura coetánea. Reuniendo estos testimonios, Teresa Jiménez Calvente ha reconstruido los mensajes proyectados sobre un rey protegido por la Providencia que habría sobrevivido a las fuerzas del mal en un contexto internacional cada vez más crispado. La correspondencia de la reina y las advertencias de diversos colaboradores (Alfonso Ortiz, Diego de Muros II, etc.), muestran igualmente las reflexiones

41 Los cronistas planteaban un singular entendimiento entre los rendidos y el ejército victorioso «como antiguos huéspedes de los cristianos, unidos todos por recíprocos sentimientos de caridad»; PALENCIA, Guerra de Granada... [ver n. 29], pp. 278-279.

42 Álvaro Fernández de Córdova Miralles, La emergencia de Fernando el Católico en la Curia papal: identidad y propaganda de un príncipe aragonés en el espacio italiano (1469-1492), en EGIDO y LAPLANA (eds.), La imagen de Fernando el Católico... [ver n. 3], pp. 61 y ss.

43 Manuel Montoza Coca trabaja actualmente en su proyecto de tesis doctoral: Sermones de Don Martín García, obispo de Barcelona. Edición y estudio.

44 Cándida FERRERO HERNÁNDEZ, Literatura latina de controversia religiosa en la Castilla del siglo XV: una aproximación a su tipología, en José MARTÍNEZ GÁZQUEZ, Óscar DE LA CRUZ PALMA, y Cándida Ferrero HernándeZ (eds.), Actas del V Congreso Internacional de Latín Medieval Hispánico, Florencia, 2011, pp. 439-440. 
suscitadas sobre el ministerio regio, y las nuevas exhortaciones a los monarcas a cultivar la clemencia, vigilar su poder, reparar «las roturas» de los infieles y animar «al Pastor Universal para que reforme los desórdenes que ha senbrado el enemigo humano, anteponiendo lo temporal a lo spiritual» ${ }^{45}$.

c) Rey muy católico: constructor de templos y reformador de la Iglesia (1493-1504)

La conclusión de la campaña granadina permitió a los reyes reimpulsar sus medidas para la restauración de la Iglesia. En este nuevo clima reformador confluyó la promoción devocional a través de la imprenta, la reforma eclesiástica y grandes proyectos arquitectónicos en la década de 1490. Münzer percibió los cambios en un Fernando entregado «a la religión, restaurando las iglesias derruidas y fundando otras nuevas», mientras Isabel se ocupaba de los «ornamentos» ${ }^{46}$; una distribución de competencias que transformaba al antiguo defensor de la Cristiandad en constructor o protector de templos, como un nuevo Carlomagno «en favor de la religión». No eran palabras vacías. En 1493 Fernando inició la edificación del monasterio jerónimo de Santa Engracia de Zaragoza, mientras Isabel se dedicaba a la cartuja de Miraflores (Burgos), sin olvidar el patrocinio conjunto sobre los conventos dominicos de Santa Cruz (Segovia) y de Santo Tomás (Ávila), los cenobios franciscanos de San Juan de los Reyes (Toledo), Santa Isabel (Toledo) ${ }^{47}$, o San Pietro in Montorio (Roma) sufragado con las rentas sicilianas para el «servicio de Dios y el mérito y honra nuestra», pues debía mostrar «la grandeza de quien la manda fazer ${ }^{48}$.

45 Véase el Tratado de la berida del rey de Alfonso Ortiz contenido en sus Cinco tratados; Biblioteca Nacional de España (Madrid) [a partir de ahora BNE], I-2246, f. 5v. Y el comentario de Teresa Jiménez Calvente en su trabajo incluido en este volumen.

46 Hieronymus MÜNZER, Viaje por España y Portugal (1494-1495), Madrid, 2002, p. 271.

47 Sobre el mecenazgo artístico del rey Católico véanse los trabajos de M. Carmen MorTe GARCía, Fernando el Católico y las Artes, en Las Artes en Aragón durante el reinado de Fernando el Católico (1470-1516), Zaragoza, 1993, pp. 155-198; a los que deben añadirse otros más específicos de la misma especialista. Joaquín YARZA LUACES, Los Reyes Católicos: paisaje artístico de una monarquía, Madrid, 1993, pp. 115 y ss; ID., Política artística de Fernando el Católico, en Ernest BELENGUER CeBrià (ed.), De la unión de coronas al Imperio de Carlos V, vol. III, Barcelona, 2001, pp. 15-29. Rafael Marcos Domínguez CASAS, Arte y etiqueta de los Reyes Católicos, artistas, residencias, jardines y bosques, Madrid, 1993. Miguel Ángel ZaLAMA RODRÍGUEZ, Fernando el Católico y las artes: pinturas y tapices, en Revista de estudios colombinos, 11 (2015), pp. 7-28.

48 Flavia Cantatore, San Pietro in Montorio: la chiesa dei Re Cattolici a Roma, Roma, 2007. FernáNDEZ DE CóRdova Miralles, Imagen de los Reyes Católicos... [ver n. 37], pp. 345-349. 
El impulso constructor es indisociable del programa reformador emprendido a partir de 1493, una vez obtenidos los permisos de Alejandro VI que ampliaban los de su precedecesor (1487) para intervenir en los monasterios de Aragón y Castilla ${ }^{49}$. Ernesto Zaragoza Pascual encara en su trabajo el caso benedictino, mostrando el esfuerzo regio por integrar todas las congregaciones en la Observancia de San Benito de Valladolid, con mejor organización, más pobreza personal, espiritualidad litúrgica y vida en común. No se oculta la pulsión autoritaria que tuvo este proceso en Castilla, donde la monarquía llevaba años impulsando dinámicas reformadoras distintas a las aragonesas, que explican la mayor condescendencia de Fernando con ciertas situaciones para mantener la unidad de la orden en sus reinos patrimoniales. La repercusión ritual de aquel proceso se materializó en espléndidas visitas a monasterios emblemáticos como Poblet, cabeza de la reforma cisterciense en los reinos de España, donde se presentó la familia real con toda su corte y recibió el besamanos de la comunidad ${ }^{50}$.

Con sus límites y sus éxitos, la reforma de Isabel y Fernando activó una sensibilidad a gran escala sin la cual no puede entenderse la labor de sus sucesores. Así lo muestra el sugestivo artículo de Tarsicio de Azcona sobre el episcopado y los derechos de presentación que los Reyes Católicos pusieron en bandeja a Carlos V ${ }^{51}$. Fueron varias décadas de arduas negociaciones con la Santa Sede que se sostenían por el ideal de los reyes -no siempre cumplido- de proveer «todas las iglesias de vuestros reinos de perlados convenibles e muy excelentes para las administraciones d'ellas, teniendo más acatamiento al espíritu, virtudes e letras de sus personas que a la nobleza e favor de linajes» ${ }^{52}$. El nivel moral e intelectual

49 Una síntesis sobre este campo de estudio, desbrozado por José García Oro y Tarsicio de Azcona, en Margarita CANTERA MonTENEgro, Las órdenes religiosas, en Miguel Ángel LaDERO QUESADA (dir.), El mundo social de Isabel la Católica, Madrid, 2004, pp. 113-126. Y las recientes investigaciones de Francisco Javier Rojo AliQue, El convento de San Francisco de Valladolid en la Edad Media (b. 1220-1518), Madrid, 2004. Guillermo NIEVA OCAMPO, La creación de la observancia regular en el convento de San Esteban de Salamanca durante el reinado de los Reyes Católicos, en Cuadernos de historia de España, 80 (2006), pp. 91-126.

50 Véase el interesante relato recogido por Jaime Finestres y DE MONSALVO, Historia del Real Monasterio de Poblet, vol. IV, Barcelona, 1948, pp. 76-79.

51 A los ineludibles trabajos de este historiador cabe añadir los de Maximiliano BARRIO GOZALO, Los obispos de la corona de Castilla en el reinado de Isabel la Católica, en Luis Antonio RIBOT GARCÍA, Julio VALDEÓN BARUQUE, y Elena MAZA ZORRILLA (coords.), Isabel La Católica y su época, vol. II, Valladolid, 2007, pp. 1115-1135; ID., Los Reyes Católicos, Cisneros y la reforma del clero secular y regular, en José Antonio Escudero LópeZ (dir.), La Iglesia en la historia de España, Madrid, 2014, pp. 415-432.

52 Importante afirmación de fray Ambrosio Montesino en el «proemio epistolar» de su Vita Christi Cartuxano, interpretado del latín en romance por fray Ambrosio Montensino, Alcalá de Henares, 1503, f. III $r$. 
alcanzado en vísperas del Concilio de Trento fue el resultado de aquella campaña de renovación y readaptación al nuevo juego de fuerzas intra Ecclesiam, donde la monarquía hispánica asumió un protagonismo que le distinguió de otras monarquías europeas ${ }^{53}$.

La política descubridora reactivó la vertiente pastoral insinuada en la campaña granadina. Eran los vientos evangelizadores que soplaron sobre la población indiana «convertible»-distinta de la «no convertible» musulmana-e impulsaron la edición de textos devocionales o los mensajes pacificadores que debían deslegitimar la agresividad de Carlos VIII de Francia. En el entorno fernandino se planteó entonces la posibilidad de solicitar a la Santa Sede el título de rey muy católico que sancionaría el ideario de la nueva monarquía, y fue concedido por Alejandro VI tres años después de que las tropas hispanas liberaran el bloqueo de Roma ${ }^{54}$. Maduraba así la consciencia eclesial del monarca que pasó de impulsar la restauración religiosa de sus reinos (reformatio in membris) a proteger al papado, e incluso reformarlo (reformatio in capite) en una singular evolución iniciada con las amonestaciones del nuncio (1493), la intervención de Gonzalo Fernández de Córdoba (1497), la de fray Bernat Boïl (1498), y finalmente la contundente embajada de 1498-99. De manera un tanto traumática reformismo y profetismo parecían caminar juntos al cumplirse los vaticinios que atribuían a Fernando la reforma de la Curia como colaborador del pastor angelicus, y las profecías isidorianas que anunciaban su dominio sobre el Papado tras tres años de sede vacante, en que «porná un santo Padre de tiempo e usança que mandó San Pedro» ${ }^{55}$.

Con todo, los ideales proféticos no podían responder al desafío ético del conflicto con Francia y el escándalo de «derramar sangre de cristianos» en el seno de una communitas identificada con el Cuerpo de Cristo, como sostenía fray Hernando de Talavera al condenar los «daños sin cuento» de la guerra «por justa que sea, especialmente contra cristianos» (1493). La ruptura de las hostilidades (1495) exigió una propaganda bélica que remilitarizó la imagen fernandina, y

53 Una reciente valoración global de Ignasi FERNÁNDEZ TERRICABRAS, «As Spanish as it was Ecumenical». Was the Catholic Reformation a Spanish Event?, en Peter OPITZ (ed.), The Myth of the Reformation, Göttinguen, 2013, pp. 32-58.

54 Álvaro FERNÁNDEZ DE CÓRDOVA MIRALlES, Reyes Católicos: mutaciones y permanencias de un paradigma político en la Roma del Renacimiento, en Carlos José HERNANDO SÁNCHEZ (coord.), Roma y España. Un crisol de la cultura europea en la Edad Moderna, Madrid, 2007, pp. 146-151.

55 Duran Grau, y ReQuesens, Profecia i poder... [ver n. 15], pp. 295-296 y 406-407. Historia de los bechos... [ver n. 33], p. 246. 
trató al rival francés con un desprecio desconocido hasta entonces ${ }^{56}$. Eran las primeras «guerras de Italia» (1495-1504) que comprometieron la imagen de defensores de la Cristiandad (protectores Ecclesiae ac Christianitatis) como Julio II recordó a los Reyes Católicos en 1504. La propaganda cortesana presentó a Fernando como rey pacificador de las discordias, intensificándose las plegarias para que «no se derramara sangre de cristianos, y el divino espíritu inspirase a los franceses y los indujera a no esperar el encuentro» ${ }^{57}$. $\mathrm{Y}$ aunque algunas composiciones celebraron la victoria de Salsas (1503) y la caída de Gaeta (1504), Isabel prohibió los festejos públicos, mientras su esposo impedía «que a ningún francés sus gentes matasen», castigando las violencias sobre la población civil y los espacios sagrados en territorio enemigo ${ }^{58}$.

\section{d) Del monarca humillado al Propagador del Imperio Cristiano (1504-1516)}

La estrella fernandina comenzó a declinar con la crisis sucesoria suscitada por los fallecimientos de los herederos: el príncipe Juan (1497), la princesa Isabel (1498) y su primogénito Miguel (1499). El revés político-dinástico suscitó una fecunda literatura para explicar la pérdida del favor divino ${ }^{59}$. Fernando retomó entonces la fisonomía del rey sufriente -incoado en su atentado de 1492- que lo equiparaba a Cristo al asumir aquella corona de sufrimientos y restaurar el desequilibrio emocional que podía desestabilizar la monarquía. Lutos y exequias adquirieron unas dimensiones desconocidas para fortalecer la adhesión interna y ocultar las manifestaciones de debilidad ante la crisis sucesoria y la crispación internacional. Fernando no perdió su energía apareciendo «alegre» ante los embajadores «pues ninguno parte de él descontento», y es «tan querido que parece el emperador Tito Vespasiano» ${ }^{60}$.

56 Alvaro FERNÁNDEZ DE CóRdOVA, El rey Católico de las guerras de Italia. La imagen de Fernando II de Aragón y V de Castilla entre la expectación profética y la tensión internacional (1493-1499), Medievalismo, 25 (2015), pp. 197-232.

57 Pedro Mártir de ANGlería, Epistolario, en Documentos Inéditos para la Historia de España, ed. por J. López de Toro, vol. X, Madrid, 1955, p. 66.

58 Continuador de Fernando del Pulgar, en Crónicas de los Reyes de Castilla, Biblioteca de Autores Españoles, vol. 70, Madrid, 1878, p. 522.

59 Jacobo SANZ Hermida, y Ángel AlCALÁ GaLVE, Vida y muerte del príncipe don fuan: historia y literatura, Valladolid, 1999. Tomás GonZÁLEZ RoláN, José Miguel BaÑos BaÑos, y Pilar SAQUero SuÁREZ-Somonte (eds.), El bumanismo cristiano en la Corte de los Reyes Católicos: las Consolatorias latinas a la muerte del Príncipe Juan de Diego de Muros, Bernardino López de CarvajalGarcía de Bovadilla, Diego Ramírez de Villaescusa y Alfonso Ortiz, Madrid, 2005.

60 Marino SANUdo, Diarii, vol. II, Venecia, 1879, col. 214. 
A pesar de todo, el trauma dinástico deterioró su legitimidad. Tras el fallecimiento de la reina (1504), no pudo evitar que las acusaciones de tiranía y los abusos inquisitoriales mancharan su imagen y debilitaran su posición ante Felipe de Habsburgo. Su expulsión de Castilla marca el punto de inflexión de aquel proceso de degradación política que remontó en su viaje a Nápoles y la recuperación de la gobernación castellana tras el fallecimiento del Habsburgo ${ }^{61}$. La pacificación con Francia le permitió retomar la expansión norteafricana bajo una nueva ideología clasicista que lo convertía no tanto en «rey católico» como en «emperador cristiano» que restauraría la Cristiandad mediterránea ${ }^{62}$. Con la renovación de las profecías de la conquista de Jerusalén, Fernando retomó las vestes del «fortísimo atleta de Cristo»-como le llamó Julio II en 1510-, y recuperó la armadura con que se hizo representar en su sepulcro granadino ${ }^{63}$.

La alianza con el papado fue el segundo apoyo de su rehabilitación, que le llevó a inéditos compromisos con la unidad eclesial -frente al cisma auspiciado por Luis XII- y máximo impulsor del V Concilio de Letrán (1512-1517) ${ }^{64}$. Fray Ambrosio Montesino le consideró entonces monarca providencial, del que pendía «toda la unidad de la yglesia militante [...] por la muy leal y cumplida obediencia que siempre ha tenido e tiene a los vicarios del hijo de Dios» ${ }^{65}$. Así compareció en la misa celebrada en Burgos ante el nuncio papal, evidenciando el valor de la Eucaristía como sacramentum unitatis y su empeño por sostener al Papado (1511). Los arcos e inscripciones clásicas que adornaron sus recibimientos desde 1507 modificaron entonces sus mensajes ideológicos, celebrando sus victorias al servicio de la Ecclesia Catholica, como sucedió en el recibimiento vallisoletano de 1513, mientras algunas medallas le representaban sosteniendo un templo en su mano izquierda aludiendo a su labor protectora $(1514)^{66}$. Eran

61 Bethany ARAM, La reina Juana entre Trastámaras y Austrias, en José Manuel NiETO SORIA, y María Victoria LÓPEZ-CORDÓN CORTEZO (coords.), Gobernar en tiempos de crisis: las quiebras dinásticas en el ámbito hispánico: 1250-1808, Madrid, 2008, pp. 31-44.

$62 \mathrm{M}^{\mathrm{a}}$ Violeta PÉrez CUSTODIO, El Panegírico de Sobrarias al Rey Fernando el Católico, en Humanismo y pervivencia del mundo clásico, Cádiz, 1993, pp. 749-758.

63 Miguel Ángel LEÓN COLOMA, Imágenes plásticas de la realeza en Granada: Fernando el Católico, el rey conquistador, en El Reino de Granada y el Nuevo Mundo, vol. II, Granada, 1994, pp. 377-410.

64 José María Doussinague, Fernando el Católico y el cisma de Pisa, Madrid, 1946.

65 Ana Ma . ÁLVAREZ Pellitero, La obra linguiistica y literaria de Fray Ambrosio Montesino, Valladolid, 1971 , p. 25.

66 Tess KNIGHTON y Carmen MORTE GarCía, Ferdinand of Aragon's Entry into Valladolid in 1513: The Triumph of a Christian King, en Early Music History, 18 (1999), pp. 119-163. Ronald SURTZ, The Entry of Ferdinand the Catholic into Valladolid in 1509, en Jelle KOOPMANS and Bart RAMAKERS (eds.), European Medieval Drama, vol. 6, Turnhout, 2002, pp. 99-108. MORTE GARCÍA, La imagen de Fernando el Católico... [ver n. 3], pp. 343-344. 
las formas de legitimación de unos proyectos que León X sancionó en la célebre representación vaticana. La titulación empleada entonces coronaba los modelos fernandinos -cruzado, devoto, evangelizador, reformador y católico- con los moldes de la teología política papal: la del Propagador del Imperio Cristiano (Christiani Imperii Propagator) que restauraría la antigua Cristiandad extendida entre Roma y Jerusalén.

\section{LA DOCTA PIETAS DEL ENTORNO FERNANDINO}

El carisma del monarca resulta incomprensible sin atender a la religiosidad vivida en su entorno cortesano, interpretado como ámbito privilegiado de su piedad, marco de representación, y caja de resonancia de las corrientes teológicas y espirituales imperantes. La sensibilidad religiosa del rey llamó la atención especialmente de los embajadores italianos; en 1498 Angelo Trevisan le consideraba «religioso y católico», y quince años después, según Guicciardini, daba «muestras de ser muy religioso, hablando con gran reverencia de las cosas de Dios y subordinando todo a esto», mostrando al mismo tiempo «gran devoción en los oficios y devociones divinas, lo cual es por cierto común a toda la nación» (1511$1513)^{67}$. Esta fama alcanzó ribetes de santidad a su muerte, por ser «santo, bueno y virtuoso, como en obras ha mostrado», ponderando Torres Naharro que «por la menor cosa suya / fuera otro canonizado» ${ }^{68}$.

Este perfil religioso no fue ajeno a los intereses culturales de un monarca considerado «prudente y sabio» por «la conversación que tuvo de hombres sabios», o los proyectos literarios y artísticos que impulsó ${ }^{69}$. En esta encrucijada cortesana fraguó una docta pietas estimulada por corrientes intelectuales como el humanismo cristiano, la teología dominica, la espiritualidad contemplativa y afectiva del franciscanismo, y unas prácticas devocionales próximas a la devotio moderna ${ }^{70}$, que se

67 SAnUdo, Diarii... [ver n. 60], vol. II, col. 214. José GARCÍA MERCADAL, Viajes de extranjeros por España y Portugal, vol. I, Madrid, 1952, p. 618.

68 Bartolomé de TORRES NAHARRO, Lamentación a la muerte del rey don Fernando, en ID., Propalladia, and other works of Bartolomé de Torres Naharro, ed. por J. Gillet, vol. I, Pennsylvania, 1943, pp. 216-222.

69 Marineo Sículo, Vida y hechos... [ver n. 34], p. 21. En 1505 los embajadores ingleses también afirman que era un monarca «muy sabio». James GAIRDNER (ed.), Memorials of Henry VII, Londres, 1858, pp. 250. Es sabido, por otra parte, que Lucio Marineo Sículo y Francesco Guicciardini advirtieron ciertas carencias en su formación humanística.

70 Para reconstruir este abigarrado panorama véanse los repertorios de Pedro SAINZ RodRÍGUEZ, Antología de la literatura espiritual española, vols. I-II, Madrid, 1980. Melquíades ANDRÉS MAR- 
manifestaron en la actividad litúrgica de su capilla ${ }^{71}$, los libros de su biblioteca ${ }^{72}$ o la literatura espiritual dirigida a su persona ${ }^{73}$. $\mathrm{Y}$ aunque nos hallemos bajo los cánones tradicionales del rex sapiens, no deben menospreciarse las representaciones con un libro entre las manos ${ }^{74}$, o recibiendo una obra religiosa a él dedicada, ni la cultura teológica que le atribuyó Hernando de Velasco al verle asistir a su hijo agonizante (1496) como «dies maestros en teología no lo pudieran más dezir» ${ }^{75}$; y como le representó Diego Ramírez de Villaescusa -con intención laudatoria- en sus Cuatro diálogos sobre la muerte del Príncipe don fuan, sosteniendo las argumentaciones filosóficas y teológicas ante las preguntas de su esposa ${ }^{76}$.

En el presente cuaderno nos ha parecido interesante dedicar algunos trabajos a este entorno religioso partiendo de la propuesta interpretativa de Maria Lurdes Rosa, que plantea valiosas reflexiones sobre la espiritualidad cortesana con interesantes aplicaciones a la corte de los Reyes Católicos tan ligada a la lusa a través de

Tín, Historia de la teología española, Madrid, 1983-1987. Las valoraciones más generales Francisco Javier FERNÁNDEZ CONDE, La religiosidad medieval en España: Baja Edad Media (siglos XIV-XV), Oviedo, 2011. Daniel de PABLO MAROTO, Espiritualidad española del siglo XVI. I, Los Reyes Católicos, Madrid, 2012. Y el monumental trabajo de Fernando GómEZ REDONDO, Historia de la prosa de los Reyes Católicos: el umbral del renacimiento, vols. I-II, Madrid, 2012. Sobre el Humanismo del reinado, añádase a los valiosos trabajos de Tomás González Rolán, el panorama y sugerencias aportadas por Teresa JiMÉNEZ CALVENTE, y Ángel GÓMEZ MORENO, Entre edenismo y aemulatio clásica: el mito de la Edad de Oro en la España de los Reyes Católicos, en Silva: Estudios de humanismo y tradición clásica, 1 (2002), pp. 113-140. Juan GIL FERNÁNDEZ, Los Studia Humanitatis en España durante el reinado de los Reyes Católicos, en Península: revista de estudos ibéricos, 2 (2005), pp. 45-68.

71 Tess Knighton, Música y músicos en la corte de Fernando el Católico, 1474-1516, Zaragoza, 2001; ID. (ed.), Companion to Music in the Age of the Catholic Monarchs, Leiden-Boston, 2016. David Nogales RinCón, La Capilla del Rey Católico: Orfebrería religiosa de Fernando II de Aragón en 1542, en Anuario del Departamento de Historia y Teoría del Arte, 19 (2007), pp. 51-66.

72 Se trata del inventario redactado en octubre de 1510 y conservado RAH, Salazar y Castro, M-198, ff 91r-107v; estudiado por Karl Rudolf, El inventario de la Cámara del Rey Católico, en Ferdinandus Rex Hispaniarum. Príncipe del Renacimiento, Zaragoza, 2006, pp. 183-191.

73 Algunas manifestaciones de su mecenazgo literario fértiles indagaciones de Ángel GóMEZ MORENO, El reflejo literario, en José Manuel NIETO SORIA (coord.), Orígenes de la monarquía bispánica: propaganda y legitimación (ca. 1400-1520), Madrid, 1999, pp. 315-340. Nicasio SALVADOR Miguel, Fernando el Católico y la literatura de su época, en MORTE García, y SESMa MuÑoz (coords.), Fernando II de Aragón... [ver n. 4], pp. 81-100.

74 Por ejemplo, su efigie en la Virgen de los Reyes Católicos (c. 1490-93) del Monasterio de Santo Tomás de Ávila, en sillería de la catedral de Plasencia (1497-1498), o recibiendo la obra que patrocina en la edición de Las Trescientas (1496), la Vita Christi de Ludolfo de Sajonia (1502) o De iustitia et iure obtentionis ac retentionis Regni Navarrae (c. 1515-1517).

75 Alvaro FERNÁNDEZ DE CóRdOVA, y Vicente CALVO FERNÁNDEZ, La muerte del heredero. Liturgia y bumanismo por el príncipe fuan en su marco europeo (en preparación).

76 Dietrich BriesemeISTER, Los Diálogos Consolatorios de Diego Ramírez de Villaescusa, en María Dolores RinCón GONZÁLEZ (ed.), Doce calas en el Renacimiento y un epílogo, Jaén, 2007, pp. 425-426. 
los enlaces matrimoniales ${ }^{77}$. Germán Gamero se ocupa de la organización de los servicios religiosos, ofreciendo un panorama institucional y humano muy útil para reconstruir el equipo de colaboradores que sirvieron al monarca en la Capilla o la Cancillería como confesores, predicadores o asesores de diverso tipo.

Finalmente, el trabajo de Martin Früh sobre Antonio Geraldini ilumina una de las corrientes más innovadoras: el humanismo cristiano impulsado en el entorno de Juan II, que establecerá fecundas sinergias con la espiritualidad catalana. A ello habrá que añadir la influencia de determinadas órdenes religiosas mediante la difusión de modelos devocionales, corrientes teológicas y advocaciones propias que dieron forma a nuevos ideales de perfección compatibles con el ejercicio del poder; sin olvidar a las figuras carismáticas de los «santos o santas vivas» que aportaron al rey Católico su estímulo y prestigio espiritual.

\section{a) Confesores e ideales de perfección}

Como centro de la corte, la persona del rey constituía el polo religioso más importante de los órganos de la Capilla y la Cancillería. Por su influencia en la conciencia y la vida espiritual del monarca resulta relevante la figura del confesor, asentado en las cortes bajomedievales como ministro del sacramento de la penitencia y asesor espiritual ${ }^{78}$. Fernando compartió sus primeros confesores con su madre, la reina Juana Enríquez: el carmelita Nicolau Ortolá (1464-1467), y los teólogos dominicos Pau Plegat y Gregorio Prestimarco (1464 y 1480), el primero catalán y el segundo de origen siracusano ${ }^{79}$. Probablemente, el futuro rey Católico también debía a su madre la inclinación por confesores dominicos mantenida el resto de su vida, añadiendo a los casos citados el de Alfonso de Mercado $(1458)^{80}$, Bernardo de Montesa (1470), Antoni Calderò (1474), y otros que

77 Véase el trabajo de la autora en el presente cuaderno.

78 Leandro MARTínez PEÑas, El confesor del rey en el Antiguo Régimen, Madrid, 2007. David NoGALES RINCÓN, Confesar al rey en la Castilla bajomedieval (1230-1504), en Ana Isabel CARRASCo Manchado, y María del Pilar Rábade Obradó, Pecar en la Edad Media, Madrid, 2008, pp. 55-79. Y la reciente investigación de Guillermo Fernando ARQUERO CABALLERO, El confesor real en la Castilla de los Trastámara: 1366-1504, en Anuario de historia de la Iglesia, 25 (2016), pp. 530-537.

79 Ciertas profecías el futuro político de Juana como reina tienen su origen en el convento dominico de Santo Domingo El Real de Toledo; cfr. Nuria Coll Juliá, Doña 7uana Enríquez: lugarteniente real en Cataluña: (1461-1468), Madrid, 1953, vol. I, pp. 75-76; vol. II, pp. 34-36, 224-225 y 228-230.

80 Miguel Gual Camarena, Servidores del infante don Fernando (1458-1462), en Estudios de Edad Media de la Corona de Aragón, 6 (1956), p. 271. 
también sirvieron como maestros, tal como Nicolàu Merola (1463, 1465 y 1470), y Rodrigo de Sese (1472) ${ }^{81}$; o predicadores, como los teólogos Antonio Ros (c. 1483 y 1494), y Juan Marqués (1476-1477) ${ }^{82}$.

De creer a Vespasiano da Bisticci, Fernando se confesaba una vez al mes y buscaba habitualmente el consejo de dominicos ${ }^{83}$; lo que favoreció la conversión de algunos en grandes colaboradores de su política eclesiástica, como Tomás de Torquemada, Diego de Deza o Juan de Enguera, sin olvidar otros casos como Tomás de Matienzo o Bernardo de Mesa, a los que Fernando asignó competencias diplomáticas o de gobierno. El rey también se sirvió de otros confesores religiosos, como Gabriel Serra -también preceptor-, el jerónimo Gonzalo de Valencia, el cartujo Juan Mercader Escolano (1504) ${ }^{84}$, el franciscano Juan de Stúñiga, y sobre todo el jerónimo Hernando de Talavera que actuó como asesor eclesiástico de primer nivel ${ }^{85}$.

Las implicaciones morales de ciertas políticas explican la influencia de estos eclesiásticos en las decisiones regias, como sucedió en 1477 en que «sus confesores le hacían conciencia y le recomendaban pagar lo que debía» a los prestamistas valencianos que le habían auxiliado ${ }^{86}$. Se trataba de un terreno difuso entre lo público y lo estrictamente personal que se advierte en la resistencia del monarca a confesarse con Matienzo en 1516 porque «venía con más fin de negociar memoriales que no en entender en el descargo de su conciencia ${ }^{87}$. Sin embargo, la salud espiritual del príncipe exigía la fortaleza y sinceridad de este eclesiásti-

81 Jaime ViCEns Vives, Historia crítica de la vida y reinado de Fernando II de Aragón, Zaragoza, 2006, pp. 168 y ss. Jorge RUBió I BALAGUER, Cultura de la época fernandina, en Fernando el Católico y la cultura de su tiempo. V Congreso de Historia de la Corona de Aragón, vol. v, Zaragoza, 1961, pp. 1011.

82 José M. Coll, Tres confesores del rey católico y la ciudad de Gerona, en Anales del Instituto de Estudios Gerundenses, 7 (1952) pp. 156-266.

83 Interesante testimonio recogido en sus Vite degli huomini illustri del secolo XV (c. 1480-1498) Vespasiano DA BISTICCI, Le vite, ed. de Aulo Greco, vol. I, Florencia, 1970, pp. 210-213.

84 Santiago Cantera Montenegro, Los cartujos en la Península Ibérica en la Edad Media, en Del silencio de la cartuja al fragor de la orden militar, Palencia, 2010, p. 54.

85 José Antonio de Herrera y Esmir, Crónica de la Provincia Franciscana de Aragón, Parte I, Diego de Larumbe, Zaragoza, 1705, pp. 252 y ss. Manuel de CASTRO, Confesores de los Reyes Católicos, en Archivo Iberoamericano, 34 (1974), pp. 96-98.

86 Carta del secretario Pedro Camanyas a Andreu Cathalà, 12 junio 1477; Felipe MATEU Y LLOPIS, Les dificultats i fretures econòmiques de Ferran el Catòlic en la guerra dinàstica castellana i llur ressò en el regne de València (1477-1480), en Estudis universitaris catalans, 15 (1930), pp. 342-343.

87 Movido por ciertos criados y «buenas personas», el rey finalmente se confesó «como católico cristiano. Y después recibió en su tiempo con devoción los sacramentos»; Alonso SANTA CRUZ, Crónica de los Reyes Católicos, ed. J. de M. Carriazo, vol. II, Madrid, 1951, p. 338. 
co como recordaba fray Gonzalo de Valencia, vicario de Santa Engracia, al rey Católico encareciéndole a que exigiera a su confesor que vigilara sus juicios de conciencia, corrigiéndole «donde yo [el rey] yerro», para que «lo mal fecho sea emendado, e de lo bien fecho sea el Senyor, e mi conciencia y real estado seguro, e por consiguiente prosperado, e mi alma descansada $\gg^{88}$.

Fray Hernando de Talavera fue probablemente uno de los confesores más influyentes, al menos desde 1475 en que firma el testamento del rey ante los muros de Toro ${ }^{89}$. A veces se tiende a minimizar su afinidad al rey alegando el proceso inquisitorial incoado contra su persona en 1505, sin embargo, los testimonios coetáneos suelen vincular al confesor con el soberano, como hace fray José de Sigüenza al comentar que «confesábanse muchas veces rey y reina [con fray Hernando] y fuera de confesión tratábanle a solas, sin encubrirle cosas de sus intentos» ${ }^{90}$. Una frecuencia que debió prolongarse más allá del nombramiento de Talavera como arzobispo de Granada (1492), pues Münzer lo consideraba «consejero de gobierno y confesor de la Magestad del Rey y de la Reina castísima», cuando visitó la corte entre 1494-1495; ${ }^{91}$ lo que confirma Lucio Marineo Sículo al señalar en 1496 que Fernando se servía del arzobispo en todo tipo de negocios confiando en su rectitud y sabiduría $(1496)^{92}$.

El carismático jerónimo no sólo atendió al monarca en el sacramento de la penitencia, sino que le proporcionó un modelo de superación moral del que es ejemplo su carta enviada con motivo del acceso de Fernando al trono de Aragón $(1479)^{93}$. Talavera le proponía un ideal de perfección secular («crecimiento de perfección»), ligado al ministerio regio y basado en el ejercicio de las virtudes y

88 Véase esta importante carta, datada el Domingo de Pasión (Cuarto de Cuaresma) en el monasterio de Santa Engracia (Zaragoza), y reproducida por Diego José DoRMER, Discursos varios de Historia, Zaragoza, 1683, pp. 171-173.

89 Sobre este importante personaje se acumula una rica bibliografía que puede reconstruirse con Miguel Ángel LADERO QUESADA, Gastar bien el tiempo y ordenar los oficios: consejos, instrucciones y ejemplos de fray Hernando de Talavera, en María Isabel DEL VAL VALDIVIESO, y Pascual MARTíNEZ SOPENA (coords.), Castilla y el mundo feudal: homenaje al profesor Fulio Valdeón, Valladolid, vol. 3, 2009, pp. 269-294. Isabella IANNUZZI, El poder de la palabra en el siglo XV: Fray Hernando de Talavera, Salamanca, 2009. Francisco José Medina, y Martin BiERSACK, Fray Hernando de Talavera, primer arzobispo de Granada. Hombre de iglesia, estado y letras, Granada, 2011.

90 José de SigüEnZA, Historia de la Orden de San ferónimo, vol. II, Valladolid, 2000, p. 320.

91 Fernando volvió a nombrar testamentario a fray Hernando, junto Diego de Deza y el prior de Santa Cruz en su testamento del 10 julio 1494; Diego de Colmenares, Historia de la insigne ciudad de Segovia, vol. II, Segovia, 1846, p. 415.

92 Lucio Marineo Sículo, De Hispaniae laudibus, Burgos, c. 1496, f. LXVIIIv.

93 El texto se recoge en Pedro de Alcántara SuAREZ y MuÑano, Vida del venerable D. Fray Hernando de Talavera: primer Arzobispo de Granada, Madrid, 1866, pp. 59-63. 
un ascetismo moderado, que rechazaba las prácticas extremas y las expresiones místicas extraordinarias ${ }^{94}$. Y aunque el jerónimo advirtiera al rey de la «muy peligrosa [situación] para el ánima» que entrañaba su acumulación de poder, estaba lejos del pesimismo espiritual de los últimos Trastámara ${ }^{95}$, pues abría al futuro rey Católico un horizonte «a la grande gloria del cielo» a partir de sus cualidades personales y «la magestad de su estado» ${ }^{96}$. Este contexto favorable a la santidad regia explicaría la exhortación de fray Francisco de Córdoba al rey para impulsar la canonización de Fernando III «porque tenéis su nombre, [...] porque venís de su linaje, $[y]$ porque heredastes la tierra quel ganó» ${ }^{97}$; interés relacionado quizá con la edición de la Coronica del sancto rey don Fernando acometida por el humanista Diego López de Cortegana a raíz de la estancia del Católico en Sevilla (1515) y concebida como posible obsequio para su nieto y futuro rey de España ${ }^{98}$. Por otra parte, tampoco hay que olvidar los modelos de santidad caballeresca asumidos por los libros de caballerías durante la regencia fernandina ${ }^{99}$, o la Crónica del buen caballero conde Fernán González (c. 1513-1514), cuya espada portó el rey Católico en Sevilla, antes de que sus huesos se removieran al presentir la caída de Granada ${ }^{100}$.

94 María MORRás RUIZ-FALCó, Ser mujer y santa (Península Ibérica, siglos XV-XVII), en Medievalia, 18/2 (2015), pp. 17-18. El modelo talaveriano conecta con esa santidad de corte, o reformismo femenino del entorno de la reina Isabel; cfr. María del Mar GRAÑA CID, Las damas de Isabel I de Castilla en los debates del humanismo sobre la autoridad y el poder de las mujeres, en Carthaginensia: Revista de estudios e investigación, 31/59-60 (2015), pp. 137-171.

95 Aunque estamos faltos de una buena investigación de base, en la corte de los últimos Trastámara se acusa una cierta desazón estoica ante la degradación política, expresada en el deseo de Juan II de haber sido «fraile [franciscano] del [convento del] Abrojo, que no rey de Castilla»; Fernán GÓMEZ DE CIUDAD REAL, Centón epistolario, Madrid, 1775, p. 175.

96 Cécile CoDet, La Suma y breve compilación de Hernando de Talavera: ¿ una guía hacia la santidad?, en Medievalia, 18/2 (2015), pp. 229-246.

97 Extractos de un libro de cosas notables sacadas de los memoriales de la librería y archivo de la iglesia de Sevilla; BNE, Ms. 5736, f. 170rv; en CARRASCO MANCHADO, Isabel I de Castilla ... [ver n. 17], p. 320.

98 José Luis GONZALO SÁNCHEZ-MOLERO, El santo rey Fernando y las «viejas corónicas» en el siglo XVI, en Fermín de los REYEs GómEZ (ed.), Crónica del santo rey don Fernando III. Edición facsímil de la de Sevilla, Jacobo Cromberger, 1516, Madrid, 2008, pp. 9-73.

$99 \mathrm{M}^{\mathrm{a}}$ Carmen MARÍN PINA, La ideología del poder y el espíritu de cruzada en la narrativa caballeresca del reinado fernandino, en Esteban SARASA (ed.), Fernando II de Aragón, el rey Católico, Zaragoza, 1996, pp. $87-105$.

100 Fernando el Católico pudo haber animado a su cronista, Gonzalo de Arredondo, a que la compusiera para la educación de su nieto homónimo, criado en la corte, como sugiere Gonzalo de ARREDONDO, Vida rimada de Fernán González, ed. por Mercedes Vaquero, Exeter, 1987, p. XVIII. Véase también Ángel GÓMEZ MORENO, Claves hagiográficas de la literatura española (del Cantar de mio Cid a Cervantes), Madrid-Frankfurt, 2008, pp. 34-35 y 75-76. 
El ideal propuesto por Talavera se basaba en una conversión personal («muy digna mudanza») para llegar a ser «otro príncipe» corrigiendo los errores «de lo pasado», y poder presentarse como un nuevo David, que inspire a su pueblo la devoción a Dios con el resplandor de su «perfección y excelencia». Consciente de que los pecados del rey habían sido cubiertos por sus propios ideales «en su muy ilustre corazón, y muchas veces publicado y a muchas personas», advertía indirectamente la necesidad de crecer para no incurrir en aquella religiosidad simulada, denunciada décadas después por Maquiavelo ${ }^{101}$. Se trata de la célebre instrumentalización religiosa que estaba más presente en la fértil imaginación del florentino que en la mente de un monarca empeñado en identificar sus intereses políticos con el bien religioso para defenderlos mejor ${ }^{102}$.

El confesor le proponía un camino jalonado de «eroicas virtudes» que armonizaran la humildad personal con una mejor representación pública («muy más autorizado y más pomposo en todas las obras de fuera»), convencido de que el progreso personal era compatible con la dignificación de su imagen, con tal de que ambas caminaran juntas ${ }^{103}$. Para evitar aparentes contradicciones le indicaba que una mayor obediencia a Dios y a los eclesiásticos, debía ir seguida de una mayor solicitud por la «justicia civil y criminal», templando los castigos como corresponde a quien debe defender y amparar al pueblo. Y el prelado que más tarde se entregaría a una intensa labor pastoral con los granadinos, aconsejaba al rey más fiereza contra los infieles y mayor mansedumbre con los cristianos.

En el terreno más personal, el confesor le animaba a crecer en el «amor y acatamiento» a su esposa, aludiendo quizá a los devaneos extramatrimoniales de quien llegó al matrimonio con dos hijos naturales ${ }^{104}$, y tuvo dos hijas naturales

101 Algunas manifestaciones bajomedievales de religiosidad simulada en NOGALES RINCÓN, La representación religiosa... [ver n. 13], pp. 129-137.

102 Sobre el contexto político que explica la envenenada alabanza del embajador florentino cfr. Miguel SARALEGUI, El príncipe afortunado: Fernando el Católico en la obra de Maquiavelo, en $\mathrm{M}^{\mathrm{a}}$ Idoya Zozorra (ed.), Virtudes políticas en el Siglo de Oro, Pamplona, 2013, pp. 29-48. Y las agudas consideraciones de LADERO QUESADA, Los últimos años... [ver n. 11], pp. 308-313.

103 Esta misma idea aplicada a la reina en Chiyo IsHIKAWA, Hernando de Tallavera and Isabelline image, en Barbara F. Weissberger (ed.), Queen Isabel I of Castile. Power, Patronage, persona, Woodbridge, 2008, pp. 71-82.

${ }^{104}$ En su testamento de 1475 Fernando no sólo confió a su esposa Isabel la crianza de sus hijos extramatrimoniales sino el cuidado de su madre; Duque de BERWICK Y DE ALBA, Noticias históricas y genealógicas de los estados de Montijo y Teba, Madrid, 1915, p. 234. 
tras su casamiento con Isabel que profesaron como agustinas en el monasterio de Madrigal de las Altas Torres (1490) ${ }^{105}$. Desgraciadamente Fernando no tuvo buenos modelos de fidelidad conyugal, pues ni su padre Juan II, ni su tío Alfonso $\mathrm{V}$ vivieron la ejemplar castidad de su abuelo Fernando $\mathrm{I}^{106}$. Los cronistas, de hecho, no ocultaron esta lacra moral con la que Fernando lidió hasta el final de sus días ${ }^{107}$, como tampoco negaron su afición a los «deportes y pasatiempos» que Talavera y Gómez Manrique le animaban a templar ${ }^{108}$.

$\mathrm{Al}$ encarecer al rey a ser más «más cierto y verdadero en toda contratación y promesa», su confesor parece advertir las quejas de los que no le consideraban «buen guardador de su palabra» ${ }^{109}$. Los cronistas justificaron este hecho señalando su sinceridad esencial, aunque «las necesidades grandes en que le pusieron las guerras, le fazían algunas veces variar [...] más por suplicaciones e ynportunidades

105 Se trata de María de Aragón y María Esperanza de Aragón, que llegaron a ser prioras del monasterio a diferencia de Juana de Aragón, la tercera hija natural del rey, que casó con el condestable de Castilla, Bernardino Fernández de Velasco; Quirino FernánDEZ, Las dos agustinas de Madrigal, bijas de Fernando el Católico, llamadas ambas Dña. María de Aragón. Documentos inéditos (1490-1548) para sus biografias, en Analecta Augustiniana, 51 (1988), pp. 5-74; también 52 (1989) y 53 (1990).

106 Tampoco la corte castellana fue particularmente ejemplar al respecto, teniendo en cuenta los escándalos de Enrique IV que comprometían el patrimonio moral de Enrique III o su hermano Fernando de Antequera, «acérrimos defensores de la castidad matrimonial»; Alfonso de CARTAGENA, El Duodenarium (c. 1442) de Alfonso de Cartagena. Cultura castellana y letras latinas en un proyecto inconcluso, ed. por Luis Fernández Gallardo y Teresa Jiménez Calvente, Córdoba, 2015.

107 Véanse los testimonios recogidos y comentados por Miguel Ángel LADERO QUESADA, La España de los Reyes Católicos, Madrid, 1999, pp. 137-141; ID., Isabel la Católica vista por sus contemporáneos, en En la España Medieval, 29 (2006), pp. 241 y ss.

108 Gómez Manrique se refería a los «juegos, caças, montería» que debía templar para «vençer el onbre a sý», en su Regimiento dirigido a Fernando hacia 1473; Gómez MANRIQUE, Cancionero, ed. por F. Vidal González, Madrid, 2003, pp. 446-450. Pulgar comenta su afición por «todos juegos, de tablas e axedrez e pelota», censurado que «en esto, mientras fue moço, gastava algund tiempo más de lo que debía»; PUlGar, Crónica... [ver n. 23], vol. I, p. 75. Flores alude exclusivamente a sus aficiones caballerescas como «grand caualgador de la brida y de la gineta, y grand echador de lança»; Julio PUYOL (ed.), Crónica incompleta de los Reyes Católicos (1469-1476): según un manuscrito anónimo de la época, Madrid, 1934, p. 88. En cambio Sículo, especifica su predilección por la caza, especialmente la cetrería, o las cartas al final de su vida; MARINEO SícUlo, Vida $y$ hechos... [ver n. 34], p. 154. Finalmente interesa reseñar la justificación de Jerónimo ZURITA, Historia del rey don Hernando el Cathólico. De las empresas y ligas de Italia, ed. A. Canellas López, Zaragoza, 1996, libro X, cap. C; y la de Solórzano Pereira al señalar que Fernando «cuando salía de caza, tenía los oídos atentos a los despachos que le leía un Secretario, y los ojos al vuelo de las garzas»; Diego SaAvedra Fajardo, Empresas Políticas, ed. Sagrario López Poza, Madrid, 1999, p. 816

109 Se trata del testimonio de Guicciardini datado entre 1511 y 1513; GARCÍA MERCADAL, Viajes de extranjeros... [ver n. 67], vol. I, pp. 618 y ss. 
de otros que por ynterese ni voluntad suya» ${ }^{110}$. Ello sin contar a los que escuchaban más de lo que el monarca había dicho, o los que rompían los compromisos, ante los cuales «el rey se gobernaba [...] tan conforme a sus tratos, y costumbres, que en todo género de prudencia se señaló entre todos ellos, aunque estuviesen más diestros en engañar al enemigo, y aventajar sus cosas por cualquier camino»111. Para no faltar a su palabra, Talavera le aconsejaba considerar mejor sus compromisos y ser más cauto en lo que firmaba, encareciéndole a contar con servidores ancianos, prudentes y sabios, y a pagar bien a sus criados, escogidos entre los fieles y diligentes ${ }^{112}$.

Talavera no se limitó a estas cuestiones morales. Su influencia también se detecta en algunos libros de espiritualidad que se encontraban en la biblioteca del rey Católico, como las traducciones de la Vita Christi del Cartujano -con su propuesta contemplativa y afectiva de la vida de Jesucristo-, o el Enseñamiento del corazón (c. 1230-1235) que también poseía Fernando, y su confesor consideraba «libro muy provechoso», que abogaba por una mayor interiorización de la vida cristiana mediante la lectura de la Biblia y el ejercicio de las virtudes, atenuando las manifestaciones exteriores de la oración vocal o las penitencias ostentosas, en una línea afín a la devotio moderna ${ }^{113}$. Se insistía así en la dimensión racional e interiorizada de la experiencia espiritual que Alfonso de Cartagena había empezado

110 Pulgar, Crónica ... [ver n. 23], vol. I, cap. XXIII.

111 Zurita señala que no sólo extranjeros, sino también algunos súbditos suyos, reprocharon a Fernando «que no guardaba la verdad y fe que prometía, y que se anteponía siempre y sobrepujaba el respeto de su propia utilidad a lo que era justo y honesto»; lo que el historiador aragonés atribuye a la degradación ética que admitía no respetar los compromisos con el que los violaba, a pesar de lo cual «el rey se gobernaba con los príncipes [...] tan conforme a sus tratos, y costumbres, que en todo género de prudencia se señaló entre todos ellos, aunque estuviesen más diestros en engañar al enemigo, y aventajar sus cosas por cualquier camino»; ZURITA, Historia del rey don Hernando... [ver n. 108], libro X, cap. C.

112 En sus testamentos de 1515 y 1516, Fernando se lamentó especialmente de no haber administrado justicia «con aquella diligencia y rectitud que devíamos [...] poniendo, ordenando y tolerando officiales y ministros no tales como al servicio de Dios Nuestro Señor y al bien de nuestro súbditos convenía»; CALDERÓN ORTEGA, y DÍAZ GONZÁLEZ, El proceso de redacción... [ver n. 9], p. 58.

113 El Ensenyamiento del coraçón figura en el biblioteca del rey Católico inventariada en 1510, f. 91v. Isabel también poseía este libro y regaló sendos ejemplares a dos hijas suyas; Elisa RUIZ GARCía, Los libros de Isabel la Católica. Arqueología de un patrimonio escrito, Salamanca, 2004, p. 179. Sobre la obra cfr. Melquíades ANDRÉS MARTíN, Teología espiritual en España (1470-1500), en Burgense, 14 (1973), pp. 215-217. Marceli GONZÁLEZ PASCUAL, «Enseñamiento del coraçón»: una traducción anónima castellana de De doctrina cordis, en Revista: Boletín de la Biblioteca Menéndez Pelayo, 78 (2002), pp. 31-68. 
a desarrollar en su Oracional (1454) que el rey Católico también conservaba en su biblioteca ${ }^{114}$.

La propuesta de buscar la perfección en el ejercicio del poder no fue la única opción espiritual en la corte de los Reyes Católicos, donde también se suscitaron vocaciones religiosas o reacciones de fuga mundi. Fernando fue testigo de la vocación eremítica de su secretario Bernat Boïl que en 1480 abandonó la corte tras una experiencia de conversión a Cristo, desde el Humanismo clásico a las Sagradas Escrituras ${ }^{115}$; un fenómeno análogo al experimentado por otros humanistas, como Antonio de Nebrija al expresar en 1495 su decisión de dedicar su vida a la filología sagrada ${ }^{116}$. El rechazo a la vida secular también se dio en los infantes que optaron por una reclusión cercana a la via mixta descrita por Maria Lurdes Rosa, consistente en traer el eremitorio a la corte, como hizo la primogénita Isabel tras el fallecimiento de su esposo $(1490)^{117}$, o su hermana Juana al adoptar ciertas formas de recogimiento y ascesis próximas a las tendencias alumbradas ${ }^{118}$. Finalmente cabe recordar a los jóvenes aristócratas educados junto al heredero, que tras su fallecimiento en 1497 tomaron los hábitos franciscanos, como Luis de Torres que «acabó sanctamente» ${ }^{119}$; o las dos hijas naturales del rey que ingresaron en el convento agustino de Madrigal, donde fueron recordadas por su ejemplaridad, espíritu reformador e intereses hagiográficos ${ }^{120}$. Todo ello nos sitúa en un ambiente cortesano polifacético donde confluyeron diversas sensibilidades y corrientes religiosas que abordaremos en el próximo capítulo.

${ }^{114}$ Luis Fernández Gallardo, La obra literaria de Alonso de Cartagena (1385-1456). Ensayo de bistoria cultural, Saarbrücke, 2012, pp. 274-277.

115 Fidel FITA, Escritos de Fray Bernal Boil, en Boletín de la Real Academia de la Historia, 19 (1891), p. 313.

116 Marcel Bataillon, Erasmo y España, México, 1956, pp. 25 y ss.

${ }_{117} \mathrm{Al}$ parecer la infanta llegó a manifestar su deseo de ingresar en el convento de clarisas de Santa Isabel de Toledo, donde fue enterrada en hábito franciscano; cfr. Manuel de CASTRO, Confesores de los Reyes Católicos, en Archivo Iberoamericano, 34 (1974), pp. 120-121. Luis SUÁREZ FERNÁNDEZ y Ramón EZQuerra Abadía, Isabel, infanta de Castilla y Aragón, en Germán BleIBERG (dir.), Diccionario de Historia de España, vol. II, Barcelona, 1986, pp. 506-507.

118 Bethany ARAM, La reina fuana: gobierno, piedad y dinastía, Madrid, 2001, pp. 146 y ss.

${ }^{119}$ Véase el testimonio de Fernández de Oviedo sobre Luis de Torres, hijo del condestable Miguel Lucas de Iranzo, mosén Girao, repostero de las camas que tomó el hábito de San Francisco, o el paje Luis Osorio que murió en la orden de San Jerónimo; cfr. Gonzalo FERNÁNDEZ DE OvIEDO, Libro de la cámara real del Príncipe don fuan e officios de su casa e seruicio ordinario, ed. por Santiago Fabregat, Valencia, 2006, pp. 87, 116 y ss.

${ }^{120}$ A la bibliografía citada, cabe añadir el impulso que ambas dieron a la composición de una de las primeras hagiografías castellanas renacentistas, la Vida del santo fray Juan de Sabagún (c. 15041511) elaborada por fray Juan Sevilla que se dirige al rey Católico para impulsar su canonización, vinculando la gloria del santo con su defensa del cristianismo; Fernando BAÑos VALLEJO, Las Vidas de santos en la literatura medieval española, Madrid, 2003, pp. 172-173. 
b) La moral del principe entre predicadores y consejeros

Algunos confesores del rey también desempeñaron el oficio de predicador, ampliando la posibilidad influir en la corte, como los citados Juan Marqués y Antonio Ros. Algunas anécdotas reflejan el impacto de este tipo de discurso, como sucedió en Zaragoza en la fiesta de San Esteban, en que el rey ponderó ante sus cortesanos la homilía de Antonio Ros: $\ll_{i} Q u e$ buenas pedradas nos ha tirado oy el padre! ${ }^{121}$. Fernando encomendó a Juan Marqués la homilía de las fiestas del Jueves y Viernes Santo, y al tener noticia de su fallecimiento (1499) su esposa Isabel se hizo con los homiliarios del teólogo valenciano ${ }^{122}$; lo que sugiere el posible intercambio de predicadores, como sucedió con Talavera, o el dominico Martín García, al que Isabel eligió como confesor tras escucharle predicar durante su estancia en Zaragoza en $1487^{123}$.

En Castilla, Fernando tuvo predicadores franciscanos como Íñigo de Mendoza, especialmente activo en los primeros años de reinado; el carismático Diego Fernández de Villalán, colaborador de Cisneros; o fray Ambrosio Montesino «su más leal y antiguo predicador y siervo» ${ }^{124}$. Entre los dominicos despuntaron reformadores como Antonio de la Peña y Pascual de Ampudia, cuya contundente homilía por el nacimiento del infante Fernando acabó adelantando su bautizo (1503) ${ }^{125}$; el teólogo García Bayón de Carvajal -capellán y prelado visitador ${ }^{126}$, y el «gracioso predicador» Bernardino de Mesa, amigo de Luis Vives y colaborador en las leyes de Burgos (1512) ${ }^{127}$. No todos los oradores fueron mendicantes, como el canónigo Alfonso Ortiz, próximo a la

${ }^{121} \mathrm{El}$ dominico había predicado en la fiesta de San Esteban durante una estancia del rey en Zaragoza; ColL, Tres confesores del rey católico... [ver n. 82], p. 149. Otras referencias en VICENS VIVES, Historia crítica... [ver n. 81], pp. 545 y 661.

122 José TOLEDO GIRAU, La librería de un obispo valenciano incautada por la reina doña Isabel la Católica, en Anales del Centro de Cultura Valenciana, 44 (1960), pp. 78-88.

123 José Manuel Montoza Coca, Hacia una edición crítica de los Sermones de Don Martín García, en Medievalia (en prensa).

124 Como se considera el propio Montesino en 1512; Ambrosio MonTesino, Cancionero de Fray Ambrosio Montesino, ed. por Julio Rodríguez Puértolas, Cuenca, 1987, p. 15.

125 Joaquín ORTega MarTín, Un reformador pretridentino, don Pascual de Ampudia, obispo de Burgos (1496-1512), Roma, 1973, p. 116.

126 Javier PÉREZ GIL, Noticias biográficas sobre Fray García Bayón de Carbajal (f 1534), obispo de Laodicea y abad del convento de Santa María la Real de Tríanos, en Archivo Dominicano, 21 (2000), pp. 314-319.

127 Testimonio de Bartolomé de Las Casas recogido en Ángel LOSADA, Luis Vives y la polémica entre fray Bartolomé de las Casas y Juan Ginés de Sepúlveda sobre las justas causas de la guerra contra los indios, en Francisco Javier FERnández NieTo, Antonio MELERo Bellido, y Antonio Mestre (coords.), Luis Vives y el humanismo europeo, Valencia, 1998, pp. 41-54. 
familia real; el obispo Valeriano Ordóñez de Villaquirán, poeta, astrólogo, músico y orador defensor del apoyo del rey Católico al v Concilio de Letrán ${ }^{128}$; o el agustino y exégeta neoplatónico Dionisio Vázquez que le siguió en su viaje a Nápoles en $1506^{129}$.

Aunque queda mucho por indagar en la oratoria palatina, algunos sermones dejaron su huella literaria. Se trata de textos compuestos en momentos políticamente relevantes, como el Sermón trobado al rey don Fernando sobre el yugo y coyundas que su alteza trahe por devisa, que compuso fray Íñigo de Mendoza durante el conflicto sucesorio (1475), donde exhorta al rey a seguir una doctrina «con que rija y con que mande», dominando a los rebeldes y protegiendo a los sojuzga$\operatorname{dos}^{130}$. Treinta años después, en la crisis sucesoria de 1504, fray Antonio de la Peña escandalizó a los colaboradores de Felipe de Habsburgo por deslizar ciertas críticas contra el Hermoso por su hostilidad al rey Católico ${ }^{131}$.

La guerra de Granada también ofreció un contexto favorable a una homilética que debía justificar la bula de cruzada y dar sentido a la campaña ${ }^{132}$. Las crónicas recogen el impacto causado por las palabras de un teólogo dominico en el sitio de Málaga durante la celebración del Jueves Santo (1487), en que «dixo cosas marauillosas, secretos grandes de la Sagrada Escriptura, esforçando mucho al rey e a sus grandes e a todos los otros caualleros y gentes en la santa fe cathólica ${ }^{133}$. Los tonos más exaltados se suscitaron a raíz de las victorias, como la misa de acción de gracias por la toma de Zahara, donde un teólogo franciscano ponderó «las grandes victoria que Dios [...] daua, de que los reyes ovieron grandísimo placer» ${ }^{134}$. Es lógico que el fin de la campaña justificara la puesta por escrito de algunas de estas homilías, como el Sermón en alabanza de los Reyes Católicos por

${ }^{128} \mathrm{M}^{\mathrm{a}}$ José SAnZ Fuentes, y José Sanz Fuentes, Valeriano Ordoñez de Villaquirán, abad de Alcalá la Real, Obispo de Oviedo (1508-1512). Documentos para la bistoria de su episcopado, en II Fornadas de historia en la Abadía de Alcalá la Real. Homenaje a D. Antonio Linage Conde, Jaén, 1999, pp. $543-$ 565. Óscar PEREa RodríGUeZ, Estudio biográfico sobre los poetas del Cancionero General, Madrid, 2007, pp. 227-231.

129 Quirino FernándeZ, Fray Dionisio Vázquez de Toledo, orador sagrado del Siglo de Oro, en Archivo Agustiniano, 60/18 (1976), pp. 105-198.

130 MendozA, Cancionero... [ver n. 18], pp. 299-318. Hugo Oscar BIZZARRI, Sermones y espejos de príncipes castellanos, en Anuario de estudios medievales, 42-1 (2012), pp. 176-177.

131 Tratamos esta cuestión en nuestra investigación en curso Fernando el Católico y fulio II. Papado y Monarquía Hispánica en el umbral de la Modernidad (en preparación).

132 Francisco BAUTISTA, Comunicación política y elocuencia sagrada en la España medieval, en Revista de poética medieval, 24 (2010), pp. 17-48.

133 Historia de los hechos... [ver n. 33], p. 264.

134 Ibid., p. 230. 
la conquista de Granada pronunciado en tierras toledanas ante los reyes en junio de 1492, o la Oratio ad Ferdinandum et Elisabeth compuesta por Alfonso Ortiz pocos meses después en Barcelona ${ }^{135}$.

La campaña norteafricana de principios del siglo XVI reactivó el discurso cruzadista. Es el caso de la «bellissima predicha» pronunciada en Nápoles por el orador pontificio Egidio de Viterbo (1506), que invitó al rey a intervenir directamente contra el Imperio Otomano ${ }^{136}$. Temática sobre la que volvió Martín García en un sermón específico sobre la conquista de Jerusalén ${ }^{137}$, o Martín Herrera a raíz de la victoria de Orán $(1509)^{138}$. Finalmente cabe recordar las piezas exaltadoras de la política eclesiástica del rey, como el sermón pronunciado en 1511 por Ordoñez de Villaquirán en la catedral de Burgos defendiendo el apoyo del monarca al concilio convocado por Julio II contra los intentos cismáticos de Luis XII ${ }^{139}$.

Algunos predicadores también desarrollaron una actividad literaria para prestigiar el ambiente moral de la corte de los Reyes Católicos, marcando el contraste con los tiempos de Enrique IV, como hizo fray Íñigo de Mendoza en sus exitosas Coplas de Vita Christi, al considerar que «para huir del diablo / es más seguro el establo / que no la casa real» ${ }^{140}$. Fernando participó de esta campaña moralizadora al recibir de fray Ambrosio Montesino su Doctrina y reprehensión de algunas mujeres contra la hipocresía de ciertos círculos femeninos, y él mismo

135 Federico Delgado SCHOll, y Oscar Perea Rodríguez, Predicación religiosa y propaganda política en el siglo XV: el Elogio a los Reyes Católicos por la conquista de Granada (1492). Edición del texto, en Voz y Letra, 13/1 (2002), pp. 3-26. GómEz REDONDO, Historia de la prosa... [ver n. 70], vol. I, pp. 859-861.

136 Marino SaNUdo, Diarii... [ver n. 60], vol. IV, col. 514.

137 Manuel MonTOZa COCA, La legitimación del poder de Fernando II de Aragón para la conquista del Reino de ferusalén secundum el Sermón XL del predicador real Don Martín García, en eHumanista, 32 (2016), pp. 586-599.

138 Martín de Herrera, Historias de la divinal victoria de Orán, eds. Pedro M. Cátedra, Juan Miguel Valero y Francisco Bautista, San Millán de la Cogolla, 2009.

139 Doussinague, Fernando el Católico y el cisma... [ver n. 64], pp. 504-512.

140 Aunque su composición es de 1467-1468, las Coplas de Vita Christi se editaron en 1482; MENDOZA, Cancionero... [ver n. 18], pp. XV y XXX-XXXI. Julio RODRÍGUEZ PUÉRTOLAS, Fray Iñigo de Mendoza y sus «Coplas de Vita Christi», Madrid, 1968, pp. 43-45. Alonso de Palencia también cargaba las tintas sobre la corrupción de la corte enriqueña en Alonso de PALENCIA, Crónica de Enrique IV, vol. I, Madrid, 1904, pp. 401-402. Por el contrario, el cronista Fernando del Pulgar aseguraba a un aristócrata receloso que en palacio «el buen caballero es mejor y el malo no tanto» (1482), mientras el comendador Hernando de Ludueña perfilaba la honesta «gentileza» imperante en la corte isabelina, y Pedro Gracia Dei elogiaba la «virtuosa doctrina» del entorno pedagógico de los infantes (c. 1486); Álvaro FERNánDEZ DE CóRDOva Miralles, La Corte de Isabel I: ritos y ceremonias de una reina (1474-1504), Madrid, 2002, pp. 89-127. 
encargó a Pedro de Cartagena censurar la deshonesta fusta entre la razón y la sensualidad que fray Íñigo dirigió a su esposa antes de $1486^{141}$.

Junto a confesores y predicadores, es preciso tener en cuenta a los preceptores, maestros y asesores que proporcionaron al príncipe las coordenadas éticas y legitimadoras para su acción gubernativa. Como heredero, Fernando contó con la enseñanza de Miquel de Morer, Antoni Vaquer (desde 1460), Joan Clapés («maestre en arts» en 1461), y especialmente su secretario Francisco Vidal de Noya (desde 1464), y su canciller Joan Margarit (c. 1466-1467) ${ }^{142}$. Con sus traducciones de Salustio, Noya le ofreció un modelo de acción política basado en la «concordia civil», y en sus poemas le describió la nobleza previa a la condición regia ${ }^{143}$. Margarit le dedicó su desaparecida Epistola seu Libellus de educatione Ferdinandi Aragoniae principis, y el tratado pedagógico Corona regum (c. 1468), que aprovecha la afición del príncipe a las piedras preciosas para ofrecerle un tratado sobre las virtudes representadas en las treinta joyas engastadas en su corona ${ }^{144}$. Curiosamente, el prelado identificó sus piedras predilectas -rubíes y perlas-, con la docilidad (docilitas) y la previsión (prouidentia), para corregir quizá la arbitrariedad de quien era «tanto fecho a su guisa que parece ninguna cosa le viene bien ni puede aprovechar, sino lo que a él le parece bien e se le antoja» ${ }^{145}$.

Durante su acceso al trono castellano, Fernando recibió una rica colección de tratados político-morales o specula principum que le interesaban lo suficiente para solicitar a su camarero, en junio de 1477, «un libro de los Regimientos de los prençipes, e otro cualquier de una buena estoria» ${ }^{146}$. El ejemplo más temprano es

${ }^{141}$ Pedro de Cartagena, Cancionero, ed. por A. María Rodado Ruiz, Cuenca, 2000, pp. 55-56.

142 ViCENS VIVES, Historia crítica... [ver n. 81], pp. 533-535.

143 Álvaro FERnÁNDEZ De CóRDOVA, Diplomáticos y letrados en Roma al servicio de los Reyes Católicos: Francesco Vitale di Noya, Juan Ruiz de Medina y Francisco de Rojas, en Dicenda: Cuadernos de filología bispánica, 32 (2014), pp. 113-154.

144 Joan MARGARIT, Corona regum, ed. por Isabel Segarra, Bellcaire d'Empordá (Girona), 2008. Aunque su editora duda de que Fernando hubiera conocido la obra, en su biblioteca se conservaba «un libro de pergamino que se llama corona de príncipes» que cabe identificar con el texto de Margarit; RUDOLF, El inventario de la Cámara... [ver n. 72], p. 188.

145 Carta de Pedro Vaca -secretario del príncipe- a Juan II, 7 octubre 1470; Antonio PAZ Y MELIA, El cronista Alonso de Palencia, Madrid, 1914, p. 108. Sobre el gusto de Fernando por las joyas cfr. M. Carmen MORTE GARCÍA, Fernando el Católico y las Artes, en Las Artes en Aragón durante el reinado de Fernando el Católico (1470-1516), Zaragoza, 1993, pp. 161-164 y 170. YARZA LUACES, Los Reyes Católicos... [ver n. 47], pp. 115 y ss. En su cámara se conservaba una corona decorada con 60 perlas, rubíes y un diamante RUDOLF, El inventario de la Cámara... [ver n. 72], p. 189.

146 Elisa RUIZ García, Los libros de Isabel la Católica... [ver n. 113], p. 429. Una aproximación al género David NOGALES RINCÓN, Los espejos de príncipes en Castilla (siglos XIII-XV): un modelo literario 
el versificado Regimiento de príncipes (c. 1471) con que Gómez Manrique le exhortaba a ejercitarse en la virtud para lograr el autodominio, la firmeza de gobierno, la equilibrada ponderación del peligro y la liberalidad ${ }^{147}$. Cinco años después otro caballero, Diego de Valera, le envió su Doctrinal de príncipes cuajado de referencias clásicas para distinguir al rey del tirano ${ }^{148}$. Pero no sólo fueron laicos quienes contribuyeron a su educación política, pues el prior general de los Jerónimos, Juan Bravo de la Laguna, se sumó a estos formadores enderezando a Fernando la traducción del De regimine principum ad regem Cypri (1475-1479) de Santo Tomás de Aquino, que aportaba su visión filosófica y teológica del ejercicio del poder ${ }^{149}$.

Clausurado el conflicto sucesorio y asentadas las bases del gobierno, la literatura especular pasó a manos de capellanes y oficiales que proporcionaron materiales argumentativos para apoyar los nuevos proyectos políticos. El capellán Antonio de Villalpando dirigió a ambos reyes el armorial moralizado Razonamiento de las reales armas (c. 1480-1487) que defendía sus empresas contra los enemigos de la fe (judíos, apóstatas o musulmanes) ${ }^{150}$; y otro capellán, Rodrigo Fernández de Santaella, les enderezó un comentario al salmo centésimo sobre el modelo davídico del rey piadoso, que tituló Guión de reyes $(1486)^{151}$. En este contexto también se deslizaron las primeras críticas a su gobierno en el Dialogo entre el prudente rey el sabio y el sabio aldeano (c. 1485-1488) (52 $^{152}$ y en las obras suscitadas por el atentado del rey (1492); es el caso del Directorio de Príncipes para el buen gobierno de España (1493) del corregidor Alonso Ramírez de Villaescusa, que intenta armonizar el autoritarismo del poder regio con el respeto de las leyes y la búsqueda del bien común ${ }^{153}$; el citado Tratado de Alfonso Ortiz (Sevilla, 1493) que perfila

de la realeza bajomedieval, en Medievalismo. Boletín de la sociedad española de estudios medievales, 16 (2006), pp. 9-39.

147 Gómez Manrique, Cancionero, ed. por Francisco Vidal González, Madrid, 2003, pp. 65, 624.

148 Cfr. Cristina MOYA GaRCÍA, El Doctrinal de príncipes y la Valeriana: didactismo y ejemplaridad en la obra de mosén Diego de Valera, en Memorabilia, 13 (2011), pp. 231-243.

149 David Nogales RinCón, En torno a la sabiduría en el cuatrocientos castellano: el prólogo a la traducción castellana del De regno ad regem Cypri de Tomas de Aquino dirigida a Fernando el Católico, en Memorabilia, 12 (2009-2010), pp. 289-350.

150 Ana Isabel CARRASCO MANCHADO, El «armorial moralizado» de Antonio García de Villalpando: heráldica y propaganda de los Reyes Católicos, en En la España medieval, No Extra 1 (2006), pp. 113-130.

151 GÓmEZ REDONDO, Historia de la prosa... [ver n. 70], vol. I, p. 469.

152 Oscar Perea RodrígueZ, La utopía política en la literatura castellana del siglo XV: el Libro de los Pensamientos Variables (BNM, ms. 6642), en Humanista. Fournal of Medieval and Early Modern Iberian Studies, 2 (2002), pp. 23-62.

153 Héctor H. GASSÓ, Las imágenes de la monarquía castellana en el «Directorio de príncipes», en Marta HARO CORTÉS (coord.), Literatura y ficción: «estorias», aventuras y poesía en la Edad Media, vol. I, Valencia, 2015, pp. 365-374. 
los próximos proyectos de su política religiosa; y la Exortación a los Reyes nuestros señores sobre el caso acaecido (Valladolid, 1493), en que Diego de Muros II previene a los monarcas de intervenir abusivamente en el foro eclesiástico, proponiendo un mejor asesoramiento de clérigos y teólogos ${ }^{154}$.

Finalmente cabe mencionar la traducción latina y castellana de las cartas apócrifas intercambiadas entre el emperador Juliano y San Basilio de Cesárea, que Fernández de Santaella publicó en su Vocabularium ecclesiasticum (1499). El texto ofrecía al rey Católico una reflexión sobre el significado de la majestad y los fundamentos de su poder, usando como contrapunto al emperador pagano que se enfrenta a Dios y ataca a su Iglesia, lo que podía interpretarse como una advertencia ante las recientes tensiones de la Corona con el Papado ${ }^{155}$. Con todo, el máximo respeto por la autoridad petrina era compatible con el empeño por la reforma «no sólo en vuestros reinos, sino en toda la cristiandad y en todo el orbe», como indicaba a los reyes su capellán Lucio Marineo Sículo en su oratio sobre la degradación de la Iglesia siciliana (c. 1500) ${ }^{156}$.

\section{c) Del dominicanismo regio a la nueva contemplación de Cristo}

Para reconstruir la religiosidad del rey Católico, es preciso considerar, junto a la veta especular, la influencia de algunas órdenes en las que el monarca volcó buena parte de sus imágenes y sentimientos de identidad político-religiosa. Fernando heredó de su madre su preferencia por los confesores dominicos, cuyo hábito vistió en su lecho de muerte como forma de ingreso póstumo, al igual que su primogénito Juan ${ }^{157}$. Tal opción debió obedecer a una distribución de afinidades religiosas con su esposa, ligada al franciscanismo, sin que ello suponga exclusividad en la relación con dichas órdenes. Fernando no sólo encomendó a los dominicos la formación de los infantes, sino que apoyó sus centros intelectuales (como San Esteban de Salamanca o San Gregorio de Valladolid), impulsó su reforma a través de la Observancia, les confió la dirección de la institución inquisitorial y

${ }^{154}$ Régula RoHLAND DE LANGBEHN, La Exortación a los Reyes, nuestros señores, sobre el caso acaescido de Diego de Muros, un De Regimine Principum de finales del siglo XV, en Atalaya, 6 (1995), pp. 81-115.

155 Joaquín Pascual Barea, Rodrigo Fernández de Santaella, en Juan Francisco DomíngueZ (ed.), Diccionario biográfico y bibliográfico del humanismo español. Siglos XV-XVII, Madrid, 2012, p. 748.

156 Teresa JimÉnEZ CaLVENTE, Las 'orationes' de Lucio Marineo Sículo (con unas notas sobre epístolas panegíricas y discursos epistolares), en eHumanista: Fournal of Iberian Studies, 22 (2012), pp. 549-551.

157 SANTa Cruz, Crónica de los Reyes Católicos... [ver n. 87], vol. II, p. 338. 
patrocinó la construcción de nuevos conventos, como los citados de Santa Cruz de Segovia o Santo Tomás de Ávila ${ }^{158}$.

Entre los teólogos dominicos más próximos al rey se hallaba el obispo de Barcelona Père García, Rodrigo Fernández de Santaella, Tomás de Torquemada y especialmente Diego de Deza, quien influyó en los últimos años de reinado como Inquisidor General y responsable de la Iglesia de Indias. Durante la regencia castellana, se ha hablado incluso de un «partido fernandino» integrado por Matienzo o Bernardo de Mesa, frente a un franciscanismo menos comprometido con su causa ${ }^{159}$. Sea como fuere, el rey puso su confianza en su prestigio moral e intelectual, delegando en Deza los problemas éticos de los repartimientos indianos en 1502, o convocando a Matías de Paz en la junta de 1512 que elaboró las leyes de Burgos, mientras impulsaba el pensamiento de tomistas como Alfonso Fernández de Madrigal, cuya obra encargó editar al doctor Palacios Rubios en $1506^{160}$.

Por influencia paterna y materna, Fernando también estrechó relaciones con los jerónimos, bien relacionados con la corte aragonesa y castellana ${ }^{161}$. En 1473 el prior general Juan de La Laguna firmó una carta de hermandad a favor del príncipe de Aragón por la que le recibía «a la espiritual hermandad de la dicha Orden» participándole «en todos los bienes espirituales» ${ }^{162}$. Más adelante

158 Entre los preceptores cabe recordar a Pedro de Ampudia y Juan López para la instrucción de la primogénita Isabel, Andrés Miranda para Juana y Catalina, y Diego de Deza para el príncipe heredero Juan; FERNÁNDEZ DE CÓRDOVA, La Corte de Isabel I... [ver n. 140], pp. 89 y ss. Guillermo NiEva OCAMPO, Servir en la Corte de los Reyes Católicos: dominicos en los oficios de tutor de príncipes y embajador (1490-1516), en Revista Chilena de Estudios Medievales, 4 (2013), pp. 61-74. Las sintonías religiosas y propagandísticas en Sonia CABALLERO ESCAMILLA, Los santos dominicos y la propaganda inquisitorial en el convento de Santo Tomás de Ávila, en Anuario de estudios medievales, 39/1 (2009), pp. 357-387. Irene GONZÁleZ HERNANDO, y Diana Olivares MARTíneZ, Los Reyes Católicos y los lugares de memoria de los santos dominicos, en José Ángel GARCÍA DE CORTÁZAR, y Ramón TEJA (eds.), Los monasterios medievales en sus emplazamientos: lugares de memoria de lo sagrado, Aguilar de Campoo, 2016, pp. 249-281.

159 José Martínez Millán (dir.), La Corte de Carlos V, vol. 1, Madrid, 2000, pp. 45-72.

160 Sobre los avatares de esta edición culminada en 1531 bajo Carlos V cfr. Luisa CuESTA GuTIÉRREZ, La edición de las obras del Tostado, empresa de la corona española, en Revista de Archivos, Bibliotecas y Museos, 61 (1950), pp. 321-334.

161 Juana Enríquez legó a esta orden los bienes y lugares que poseía en Castilla, con la obligación de edificar un monasterio, como también hizo Juan II al ordenar en su testamento la edificación de Santa Engracia de Zaragoza; Carmen MuÑOZ RoCA-TALladA, Doña fuana Enríquez: madre del rey católico, Madrid, 1945 , pp. 200-201. Sobre las sintonías de los jerónimos con la corte castellana cfr. Miguel Ángel LADERO QUESADA, Mecenazgo real y nobiliario en monasterios españoles los ferónimos (siglos XV y XVI), Príncipe de Viana. XLVII (1986), pp. 409-439.

162 Archivo General de Simancas (Valladolid), Patronato Real, leg. 27, doc. 83. 
los jerónimos apoyaron al regio matrimonio en el conflicto con Portugal, y en 1475 Fernando designó como posible sepultura el monasterio de Nuestra Señora del Prado, del que era prior Talavera ${ }^{163}$. El monarca visitó en repetidas ocasiones el monasterio de Guadalupe, y sufragó la construcción del monasterio de Santa Engracia en Zaragoza, para cumplir la voluntad de su padre y en agradecimiento al servicio de la orden en «nuestros reinos de Castilla» ${ }^{164}$.

Finalmente hay que mencionar la poderosa influencia franciscana en el entorno del rey ${ }^{165}$. Su padre se había servido en confesión del maestro fray Marco $\mathrm{Berga}^{166}$, y su madre pertenecía a uno de los linajes más afines a la orden ${ }^{167}$, manteniendo ella misma contacto con las terciarias del convento de Santa María de Jerusalén (Barcelona ${ }^{168}$. El impulso de los Reyes Católico a la rama observante, se concretó en la construcción de monasterios y una presencia de observantes en la corte que no pasó desapercibida al nuncio papal en $1493^{169}$. Intelectualmente el rey mostró cierta afinidad al pensamiento de Ramon Llull, cuya utopía de conversión religiosa pudo conectar con el profetismo ligado a su persona. También favoreció la doctrina del místico mallorquín protegiendo a Bartomeu Caldentey y a Pere Daguì -capellán suyo desde $1487^{170}$ - y, a pesar de la oposición inquisitorial, promocionó cátedras lullistas en Mallorca, Barcelona y Valencia, mientras Cisneros lo hacía en la nueva Universidad de Alcalá (1508) ${ }^{171}$.

Fernando también pudo conocer el escotismo a través de su maestro Francisco Vidal de Noya. Años después recibió el Viridarium virtutum (1504-1506)

163 SigüEnZA, Historia de la Orden... [ver n. 90], vol. II, p. 26. Testamento de Fernando de Aragón, Tordesillas 12 julio 1475; BERWICK Y DE ALBA, Noticias históricas... [ver n. 104], pp. 232-234.

164 Carmen MORTE GARCÍA, El monasterio jerónimo de Santa Engracia de Zaragoza en el mecenazgo real, en Santa Engracia. Nuevas aportaciones para la bistoria del monasterio y basílica, Zaragoza, 2002, pp. 102-178.

165 Véase el análisis y actualización de José Manuel NIETO SORIA, Franciscanos y franciscanismo en la política y en la corte de la Castilla Trastámara (1369-1475), en Anuario de Estudios Medievales 20 (1990), pp. 109-132.

${ }^{166}$ Juan II le encomendó alguna misión diplomática y contó con su presencia en el momento de su muerte Jerónimo ZURITA, Anales de Aragón, Zaragoza, 1977, libro XVIII, cap. LVIII.

167 Manuel DE CASTro, El Real Monasterio de Santa Clara de Palencia y los Enríquez, Almirantes de Castilla, Palencia, 1982.

168 Antoni Paulí MelÉNDEZ, El reial monestir de santa María de ferusalem de Barcelona, Barcelona, 1970.

169 Véanse los trabajos de José GARCÍA ORO, Cisneros y la reforma del clero español en tiempo de los Reyes Católicos, Madrid, 1971; ID., El Cardenal Cisneros. Vida y empresas, vols. I-II, Madrid, 1992-93.

${ }^{170}$ Lorenzo PÉREZ MARTÍNEZ, El maestro Daguí y el lulismo mallorquín de fines del siglo XV , en Estudios Lulianos, 4 (1960), pp. 291-306. Rafael RAMIS BARCELÓ, En torno al escoto-lulismo de Pere Daguí, en Medievalia, 16 (2013), pp. 235-264.

171 Álvaro SANTAMaría, La promoción universitaria en Mallorca. Época de Fernando el Católico, Palma, 1983, pp. 85 y ss. Jordi RUBIÓ I BALAGUER, Humanisme i renaixement, Barcelona, 1990, p. 195. 
dedicado por el teólogo Juan López de Ayora ${ }^{172}$, y a fines del reinado permitió la entrada del nominalismo en Alcalá, Salamanca, Valladolid, Zaragoza, Osma, Huesca $^{173}$. Con ello se instalaron en los reinos las tres vías de Santo Tomás, Escoto y nominales como algo que pertenecía a la visión integral de la teología, y el deseo de acceder a la verdad mediante un bagaje intelectual complementario que preparó a la teología hispana para los desafíos de la modernidad. Algo nada extraño en un monarca tan pragmático en sus decisiones como receptivo a las novedades que se le presentaban.

Finalmente, debemos referirnos al grupo de mujeres, o beatas, vinculadas a las órdenes terceras, que se consagraban a Dios sin abandonar el estado laico y manifestaron carismas visionarios como «santas vivas». Con su esposa Isabel, Fernando auspició a las beatas María de Ajofrín -jerónima-, y María de Toledo, vinculada a las clarisas del convento toledano de Santa Isabel de los Reyes, al que el rey donó ciertas casas pertenecientes a su madre ${ }^{174}$. En este contexto sensible a las manifestaciones de santidad, se comprende su relación con Santa Beatriz de Silva -dama de Isabel y fundadora de la orden de las Concepcionistas- y con su hermano el beato Amadeo, fundador de la rama observante de los franciscanos amadeítas. Con la edificación del convento de San Pietro in Montorio encomendado a esta congregación, el rey Católico recompensaba la intercesión de Amadeo por la obtención de un heredero varón, el príncipe Juan nacido en 1478, consolidándose una amistad que explica el apoyo del monarca a la confirmación pontificia de la orden fundada por su hermana $(1511)^{175}$.

El rey también mantuvo contacto con el santo taumaturgo Francisco de Paula, fundador de los Mínimos, que le animó a través de emisarios a mantener el

172 Una versión manuscrita y miniada en la Bibliothèque et Archives du Château de Chantilly, Ms. 300. Júlia BENAVENT, Biblioteca dispersa: manuscrits i Incunables Valencians dels segles XIV al XVII, Valencia, 2007, pp. 141 y ss.

173 Melquíades ANDRÉS MARTíN, La teología española en el siglo XVI, Madrid, 1977, p. 291.

174 Ángela MUÑOZ FERNÁNDEZ, Notas para la definición de un modelo sociorreligioso femenino: Isabel I de Castilla, en Las mujeres en el cristianismo medieval. Imágenes retóricas y cauces de actuación religiosa, Madrid, 1989, pp. 415-434, p. 423. FERNÁNDEZ DE CóRDOvA, La Corte de Isabel I... [ver n. 140], pp. 167-171.

175 Hasta la creación de una comunidad en los palacios de Galiana (1484), Beatriz vivió como «seglar honesta» en el monasterio de Santo Domingo el Real, cuya priora, Catalina de Castilla era tía del rey Católico; José Miguel LóPez CuÉTARA, Documentos relativos a la Orden de la Inmaculada Concepción (1489-1975), Burgos, 1993, pp. 36-38. Nicasio SALVADOR MigUEL, Isabel la Católica: educación, mecenazgo y entorno literario, Alcalá de Henares, 2008, pp. 27-28. María del Mar GRAÑA CID, Beatriz de Silva (ca. 1426-ca. 1491), Madrid, 2004, pp. 20 y 62. 
cerco de Málaga (1487) anunciándole la caída de Granada, e intercedió ante el rey de Francia para que devolviera los condados pirenaicos $(1482-1493)^{176}$. Fernando pudo contactar con el santo a través de Bernat Boïl, enviado a Francia y futuro vicario de los mínimos en Castilla y Aragón ${ }^{177}$.

$\mathrm{Al}$ final de su vida, el rey intensificó su relación con algunas visionarias con las que debió compartir su espiritualidad afectiva y su sensibilidad profética. Visitó varias veces a la beata Marta de la Cruz, vinculada al monasterio de San Clemente de Toledo, encomendándose a sus «oraciones y contemplaciones» en mayo de $1509^{178}$. Un año antes, en febrero de 1508, convocó en Burgos a la terciaria dominica María de Santo Domingo, la «beata de Piedrahita», a la que protegió a través de sus confesores Juan de Enguera y Tomás de Matienzo en el proceso que finalmente la absolvió. Fernando le otorgó diversas mercedes en los años siguientes y amparó su convento fundado en Aldeanueva, manteniendo la relación a través de ciertos consejeros hasta su fallecimiento en 1516, poco antes de recibir de la beata la predicción de que no moriría sin haber recuperado Jerusalén ${ }^{179}$.

En el terreno espiritual, el calendario litúrgico de la capilla fernandina y su orfebrería religiosa refleja una espiritualidad fundada en la vida de Cristo, especialmente en su Encarnación y en su Pasión y Resurrección ${ }^{180}$; los dos principios dogmáticos que el monarca invocó al inicio de sus testamentos de Burgos (1512), Aranda (1515) y Madrigalejo (1516). A esta base teológica se sumó la contemplación demorada y afectiva de Cristo impulsada por el franciscanismo,

${ }^{176}$ José Miguel DíAZ de EsCOVAR, La imagen de nuestra Señora de la Victoria. Patrona de Málaga. Estudio Histórico, Málaga, 1898, pp. 7-11. ZuRITA, Historia del rey don Hernando... [ver n. 108], libro I, cap. IV.

177 A los trabajos de Fidel Fita, cabe añadir Albert LAMBERT, Boil (Bernat ou Bernal), en Dictionnaire d'Histoire et Géographie Ecclésiastique, vol. IX, París, 1937, cols. 523-528. Mariàngela VILALLONGA, La literatura llatina a Catalunya al segle XV. Repertori biobibliogràfic, Barcelona, 1993, pp. 38-43.

178 José García ORO, Cisneros: un cardenal reformista en el trono de España (1436-1517), Madrid, 2005, pp. 185-191. Geraldine MCKENDRICK and Angus MACKAY, Visionaries and Affective Spirituality during the First Half of the Sixteenth Century, en Mary Elizabeth PERRY y Anne J. CRUZ (eds.), Cultural Encounters: The Impact of the Inquisition in Spain and the New World, Berkeley, 1991, pp. 93-104.

179 Rebeca Sanmartín BaStida, La Representación de las misticas: Sor María de Santo Domingo en su contexto europeo, Santander, 2012. Noticias sobre las mercedes regias entregadas a esta beata identificada por LADERO QUESADA, Los últimos años... [ver n. 11], pp. 142-143 y 354.

180 En los citados trabajos de Zalama y Nogales se documentan tapices con los gozos y dolores de la Virgen, esculturas de plata de Nuestra Señora con el niño en brazos, crucifixiones con las armas reales, relicarios y portapaces con la representación de la Pasión del Señor, incluyendo a veces la Resurrección y las armas de Aragón. 
y manifestada en la promoción de la Vita Christi de Francesc Eiximenis o la exitosa de Ludolfo de Sajonia, la obra espiritual más célebre del tardío Medievo y temprano Renacimiento ${ }^{181}$. No es extraño que sus respectivas traducciones fueran acometidas por su confesor Hernando de Talavera, y su predicador Alonso Montesino ${ }^{182}$. Fernando participó en el proyecto cediendo a su esposa a su iluminador Alonso Jiménez para la traducción de la obra Ludolfo ${ }^{183}$, cuya edición (1502-1503) -conservada en su biblioteca- llevaba en portada la representación del regio matrimonio recibiendo la obra ${ }^{184}$. El monarca se interesó por la traducción valenciana aparecida siete años antes $(1495-1500)^{185}$, solicitando un ejemplar al batle general -encargado de sus bienes- en marzo de 1496, por «que es muy buena obra, la qual nós queremos haver en todo caso» ${ }^{186}$. Cabe preguntarse, incluso, si estuvo relacionado con la publicación de la Vita Christi (1496) que Isabel de Villena dedicó a la reina, como abadesa del convento de la Trinidad (Valencia), a quien el rey confió en 1484 la custodia de su hija natural, María de Aragón ${ }^{187}$.

La contemplación íntima y afectiva de Cristo también impulsó las coplas de devoción emprendidas en la década de 1480 por Ambrosio Montesino y editadas en el Cancionero de 1508 por el empeño del monarca, que ordenó «muchas ve-

181 Eugenio ASENSIO, El erasmismo y las corrientes espirituales afines: conversos, franciscanos, italianizantes con algunas adiciones y notas del autor, Alicante, 2011.

182 Albert Hauf I VAlls, Fray Hernando de Talavera, O.S.H., y las traducciones castellanas de la Vita Christi de Fr. Francesc Eiximenis, O.F.M., en Tomás MARTínEZ ROMERO, y Roxana RECIO (eds.), Essays on Medieval translation in the Iberian Peninsula, Castelló-Omaha, 2001, pp. 203-250.

183 YARZa LuACES, Política artística... [ver n. 47], p. 27.

${ }^{184}$ En el inventario de 1510 figura la «Primera parte del Cartuxano» (95r), y la «dos libros llamados la Segunda parte del Cartuxano» (91v); cfr. NOGALES RINCÓN, En torno a la sabiduría... [ver n. 149], p. 304.

185 Diego ROMERO LuCAS, La traducción valenciana de las «Meditationes Vitae Christi» del cartujano Ludolfo de Sajonia: las primeras ediciones valencianas impresas, en Quaderns de filologia. Estudis literaris, 8 (2003), pp. 299-314.

${ }^{186}$ Fernando utilizó el mismo procedimiento usado por su esposa para obtener la obra homónima de Isabel de Villena, y que por motivos editoriales comenzó publicándose Lo quart del Cartoxà; Martín de RIQUER, Història... [ver n. 14], vol. III, pp. 257 y 454-455.

${ }^{187}$ En la biblioteca del monarca se conservaba un «libro guarnecido en tablas y terciopelo negro con VIII chatones y tres enbrillas y hun marho de plata que se llama vita christi» distinto al Cartujano -citado expresamente en otro item - y cabría identificar con la obra de Isabel de Villena; M. Carmen MorTe GarCía, El viaje de los príncipes de Castilla y Aragón a Zaragoza en 1502, en Miguel Ángel ZaLAMa RodRíGUEZ (dir.), fuana I en Tordesillas: su mundo, su entorno, Valladolid, 2010, p. 66. Albert HaUf I VALLS, D'Eiximenis a sor Isabel de Villena. Aportació a l'estudi de la nostra cultura medieval Barcelona, 1990, p. 323. Isabel de VILLENA, Vita Christi, ed. por A.-G. Hauf i Valls, Barcelona, 1995. 
zes» su recopilación ${ }^{188}$. Eran textos de consumo oracional solicitados por diversos cortesanos, y destinados a un uso devoto, quizá litúrgico, que nacen de contemplaciones, prédicas y meditaciones sobre la vida de Cristo y de María en su doble vertiente navideña y pasional. Una de sus composiciones más extensas, dedicada a San Juan Bautista, fue solicitada por Fernando «para que se escriba lo que se reza / de su gracia e aspereza»; es decir para aprender a rezar con la elegancia de la lengua vernácula. De hecho el predicador franciscano glosa la narración de Lucas (1, 39-56), e incluye su propia oración a Santa Ana o la Virgen María, introduciendo amonestaciones al auditorio, como la citada Doctrina y reprehensión de algunas mujeres como contrapunto a los modelos bíblicos.

El encargo más ambicioso que el rey Católico solicitó a Montesino fue la traducción y revisión de las Epistolas y evangelios por todo el año (c. 1515), que décadas antes había emprendido su cronista Gonzalo García de Santa María. La propuesta obedecía a uno de los ideales más genuinos del humanismo vernáculo que buscaba el contacto directo con los textos sagrados. La nueva traducción debía facilitar a los seglares un «misal» para comprender los textos escriturísticos leídos intra Missam, con la ayuda de las homilías anejas -pero separadas- de Iohannes Herolt de Basilea ${ }^{189}$. Texto sagrado y culto litúrgico se ensamblaban así en una obra inspirada por propósitos oracionales, reformistas y pastorales difundidos por Talavera en su sede granadina, e impulsados ahora por Fernando en virtud del «muy gran fruto spiritual que de la comunicación deste libro viene a los que no saben latín», incluido el rey que conservaba un ejemplar en su biblioteca ${ }^{190}$.

La celebración litúrgica del misterio de Cristo también impregnó el humanismo cristiano cultivado en la corte en la década de 1480. Uno de sus protagonistas, Antonio Geraldini, dedicó al rey los perdidos Fastorum libri Ferdinandi Catholici Hispaniarum regis, mientras enderezaba a su esposa un libro de horas en clave humanista titulado Epodom liber primus (c. 1485-1487). Como señala Martin Früh en su excelente trabajo, el secretario regio planteó una adaptación cristiana del calendario poético de Ovidio, explicando el año litúrgico y las fiestas cristia-

188 Como señala en su «significación epistolar», el monarca «me ha muchas vezes mandado [...] que ayuntase en un breue compendio todos los tratados que de algunas materias e misterios de nuestra muy Santa Fe yo he rimado de coplas de deuición en tienpos pasados»; cfr. Álvaro BUSTOS TÁUlER, Ambrosio Montesino y el «Exercicio de la continua predicación»: poesía, mecenazgo y sermón en su «Cancionero» (Toledo, 1508), en Revista de poética medieval, 24 (2010), pp. 93-126.

189 Ana Má. Álvarez Pellitero, La obra lingiuistica y literaria de Fray Ambrosio Montesino, Valladolid, 1971.

190 Probablemente se trata del «otro libro llamado Epístolas y Evangelios» (95r), que se conservaba en el inventario; NOGALES RinCón, En torno a la sabiduría... [ver n. 149], p. 304. 
nas con dísticos elegíacos compuestos con el mejor latín de su tiempo. Ofrecía así una sorprendente trasmutación del presente histórico y la bistoria salutis, donde el mundo romano era sustituido por el Christianum imperium restaurado por Fernando al recuperar territorios a la fe cristiana. Una idea análoga a la del oficio litúrgico sobre la conquista de Granada, que celebra la victoria en el grandioso marco de la historia de la salvación, o el Misal de la Biblioteca Vaticana (15061507) que incorpora -en el oficio del Viernes y Sábado Santo- oraciones dotadas de su propia melodía dirigidas al rey Católico como vencedor y propagador de la fe, a las puertas de la Resurrección de Cristo, y en el lugar que el oficio romano reservaba al papa ${ }^{191}$.

Como es sabido, la espiritualidad cristológica tuvo una deriva hacia los misterios de la Pasión y Muerte a fines del siglo $\mathrm{XV}^{192}$. Los primeros conatos pasionistas se documentan en la corte de Enrique IV -devoto de la Pasión y la sangre de Cristo ${ }^{193}$ - y en la de Juan II de Aragón que falleció besando un crucifijo con elocuentes manifestaciones de arrepentimiento y devoción ${ }^{194}$. Sin embargo, los acentos emotivos y contemplativos se intensificaron en el reinado del rey Católico, que apeló en sus sucesivos testamentos a la «su muy preciosa sangre» (1475), o a «los méritos de la sacratísima Pasión de su bendito Hijo, que con su preciosa sangre la [su alma] redimió» $(1516)^{195}$. En este último documento Fernando también alude al «árbol de la Vera Cruz» donde Cristo padeció «el suplicio de dura y cruda muerte», usando la misma expresión empleada por su padre en la carta que le remitió en su lecho de muerte ${ }^{196}$. Y en 1496 recordó a su agonizante primogé-

191 Tess KNIGHTon, Política y religión en la capilla real aragonesa: El misal-breviario de Fernando el Católico, en José MARTínez MiLlán, Manuel Rivero RodríGUEZ, y Gijs VERSTEEGEN (coords.), La corte en Europa: política y religión (siglos XVI-XVIII), vol. I, Madrid, 2012, pp. 80-84.

192 Cfr. José SÁncheZ Herrero, Pasión y sangre. En torno al origen de las cofradías de Semana Santa hispana», en Daniel BaLoup (ed.), L'enseignement religieux dans la Couronne de Castille. Incidences spirituelles et sociales (XIII $-X V^{e}$ siècle), Madrid, 2003, pp. 125-142.

193 NoGALES RinCón, La representación religiosa... [ver n. 13], pp. 54 y ss.

194 El rey moribundo cogió varias veces en sus brazos el crucifijo que había adornado su capilla y, llorando, besaba los pies de Cristo «molt piadosament e ab gran devotio e reverentia» invocando su misericordia; Pere Miquel CARBOnELl, De la enfermedad y exequias del rey don fuan II de Aragón, en Opúsculos inéditos, ed. por M. de Bofarull y Sartorio, Colección de documentos inéditos del Archivo de la Corona de Aragón, vol. XXVII, Barcelona, 1864, pp. 191-192.

195 El testamento de 1475 en BERWICK Y DE ALBA, Noticias históricas... [ver. n. 104], pp. 233 y ss. El de 1515 y 1516 en CALDERÓN ORTEGA, y DÍAZ GONZÁLEZ, El proceso de redacción... [ver n. 9], pp. 43-90.

${ }^{196}$ El texto de esta misiva del 18 enero 1479, en José Ángel SESMA MuÑoz, Fernando de Aragón: Hispaniarum Rex, Zaragoza, 1992, pp. 270-271. En el testamento de Madrigalejo Fernando comenta su esperanza en «el fruto de la Cruz, e de su sacratísima Pasión, e de la preciosíssima sangre que en ella por nuestra redempción derramó, e recorremos a ella como a única esperança»; y más 
nito este misterio consolador: «Acuérdate, hijo muy amado, de Christo pendiente en la cruz y cuántos dolores era su ánima afligida en la agonía de la muerte» ${ }^{197}$.

Knighton ha puesto de manifiesto el gusto de su capilla por cultivar en polifonía textos litúrgico/devocionales relacionados con las festividades de la Cruz y la Semana Santa, empleando una combinación de música y texto único en su género ${ }^{198}$. La devoción debió extenderse por el auge de la literatura pasionista, con obras tan señeras como la Pasión trovada de Diego de San Pedro, difundida entre el gran público hacia 1480, a la que siguieron las Coplas de la Pasión con la resurrección (1490) escritas por el comendador Román por «mandamiento» del «Rey muy devoto» y su esposa, a los que exhorta a contemplar el misterio pascual en una repentina trasmutación de su palacio en la corte de Cristo, donde «los apóstoles [son] galanes, / y las damas las Marías; / adonde las condiciones / desta corte sin bolliçios, / las fiestas eran pasiones, / lágrimas las colaçiones, / los brocados los çilícios» ${ }^{199}$. En la misma década también se compuso la Istoria de la Passio y de la Contemplacio a Fesus crucificat (1493) debidas al poeta valenciano Bernat Fenollar, que desde 1479 servía al rey como «escrivà de ració» y «capellà e mestre de capella». Como ha mostrado Garcia Sempere, no se trataba sólo de facilitar la contemplación de la Pasión o la oración personal, sino de aportar una narración más teológica dirigida a un público más selecto, probablemente corte$\mathrm{sano}^{200}$. De hecho, la capilla del rey fue un semillero de piezas musicales de gran calidad relacionadas con el Misterio Pascual, y otras literarias como la Passio Domini secundum Matthaeum hexametris versibus composita (Sevilla, c. 1500) elaborada por Lucio Marineo Sículo a petición de sus colegas capellanes ${ }^{201}$.

A esta literatura devocional en lengua vernácula y latina, hay que añadir los tratados catequéticos difundidos en la década de 1490 a través de la imprenta y

adelante apela a su redención y «la multitud de sus grandes misericordias» para enmendar sus faltas con «las rodillas puestas en el suelo con el mayor remordimiento de consciencia e arrepentimiento de corazón, que no es posible por nuestra flaqueza».

197 Véase el relato de Alonso Ortiz en González Rolán, BaÑos Baños, y Saquero SuáreZSOMONTE (eds.), El humanismo cristiano... [ver n. 59], pp. 380-381.

198 Tess Knighton, Fernando el Católico y el mecenazgo musical de la corte real aragonesa, en Nassarre: Revista aragonesa de musicología, 9/2 (1993), pp. 44-45.

199 Comendador Román, Coplas de la Pasión con la Resurrección, ed. por Giuseppe Mazzocchi, Florencia, 1990, pp. 95-96.

200 Maria Manuela Garcia SemPere, La Pasión trovada de Diego de San Pedro y la Istòria de la Passió de Bernat Fenollar y Pere Martines. Algunos paralelos, en El retrato literario, tempestades y naufragios, escritura y reelaboración, Madrid, 2000, pp. 509-521.

201 Teresa JimÉnez CaLVENTE, Algunas precisiones bibliográficas con base en la obra de Lucio Marineo Sículo, en Revista de Literatura Medieval, 11 (1999), pp. 255-266. 
al amparo de la Corona, que desarrollaban temas medulares de la fe cristiana atendiendo especialmente a la dimensión redentora de la Pasión y su actualización eucarística. Uno de los primeros fue el Luzero de la vida cristina (1493) que Pedro Jiménez de Préjano -obispo y miembro del Consejo Real- compuso «por mandado» de Isabel y Fernando para explicar los artículos de la fe con ciertos desarrollos teológicos y mentalidad reformadora, para que los cristianos ignorantes, musulmanes o conversos se dieran cuenta de la dignidad de los principios cristianos a los que debían ajustar sus vidas ${ }^{202}$.

Más ligada a la corriente pasionista se halla la traducción de Gauberto Fabricio de Vagad, cronista del rey Católico, de la Pasión de Cristo (c. 1493) perteneciente al Monotheseron de Jean Gerson ${ }^{203}$; y el Tesoro de la Pasión (1494) que enderezó a los monarcas el converso aragonés Andrés de Li con una sofisticada colección de imágenes que debían ayudar a extraer los significados pertinentes a la redención humana en una moderna simbiosis de representación visual y piedad contemplativa $^{204}$. En este contexto se vio la necesidad de redescubrir la actualización del sacrificio de Cristo en la celebración eucarística, como hace el tratado Memoria de nuestra redención, atribuido a Hernando de Talavera (c. 1475-1479) y editado en 1497 para satisfacer el deseo de los reyes de «ver por algún devoto estilo escrito el entendimiento de todo lo que en este muy santo memorial de nuestra redención se hace ${ }^{205}$. El jerónimo atribuye esta iniciativa a Isabel y Fernando que, «con el zelo de su santa devoción y deseo», ordenaron a un grupo de teólogos examinar el tratado y «lo mandaron imprimir para que fuesse comunicado con los fieles», por ser un libro «de mucha devoción y muy necessario para la hedificación y salvación de las animas» ${ }^{206}$. No se trataba de mera apologética, sino de facilitar la compren-

202 La obra tuvo varias reediciones y fue traducida al catalán (Barcelona, 1496); cfr. GóMEZ REDONDO, Historia de la prosa... [ver n. 70], vol. I, pp. 1028-1052.

203 António-José D’ALMEIDA, A paixâo do «Monotessaron» de Gerson, traduzida pelo cisterciense Fr. Gauberto de Vagad sua ilustraçâo em «La pasion de Cristo» da British Library (1493?), en Los caminos de Santiago y la vida monástica cisterciense, vol. II, Zamora, 2010, pp. 669-691.

204 GómeZ Redondo, Historia de la prosa... [ver n. 70], vol. I, pp. 903 y ss. José Fradejas LeBrero, Andrés de Li (1455?-1521), en Actas del XIII Congreso Internacional de la Asociación Hispánica de Literatura Medieval, Valladolid, 2010, pp. 67-85 Andrés DE LI, A Scholarly Edition of Andrés de Li's Thesoro de la Passion (1494), ed. por L. Delbrugge, Boston, 2011.

${ }^{205}$ El privilegio se expidió a nombre de Sancho Pérez Machuca, que podemos identificar con «Sancho de Machuca», que recibió de los reyes ciertas mercedes en pago a sus servicios, en Medina del Campo el 12 septiembre 1504; Rosana de ANDRÉs DÍAZ, El último decenio del reinado de Isabel I a través de la tesorería de Alonso de Morales (1495-1504), Valladolid, 2004, p. 962.

${ }^{206}$ Jesús R. FOLGADO GARCÍA, «La expositio missae» «Memoria de nuestra redención», un posible texto franciscano atribuido al confesor regio el jerónimo Hernando de Talavera, en Iacobus: revista de estudios jacobeos y medievales, 33-34 (2015), pp. 169-198. 
sión de los gestos litúrgicos a través de la Escritura y los comentarios de los padres, sin incurrir en abusos alegóricos, buscando un moderno acceso a las fuentes y una interiorización de la piedad en la línea de otros proyectos fernandinos.

\section{DEVOCIONES Y ESCENARIOS}

\section{a) Ante la cortina real: la piedad litúrgica del rey}

Junto al discurso religioso difundido desde la corte, es preciso valorar la actividad litúrgica y devocional del rey en el marco de su capilla. El acto de culto por excelencia era la Eucaristía, por la que Fernando sintió una devoción heredada de su padre Juan II, que «oýa deuotamente la missa y no se le passaua día sin oýrla» ${ }^{207}$. Como príncipe contó con los ornamentos necesarios «per a que’l dit senyor infant hoys missa»; y una vez convertido en rey de Castilla y Aragón asistía diariamente y comulgaba una vez al $\mathrm{mes}^{208}$. Algunas fuentes castellanas ponderan incluso la «grandísima reuerençia y lágrimas en sus ojos» con que el rey «confesaua e commulgaua muchas veces en el anno» ${ }^{209}$; afirmación más o menos tópica que contrasta con las escasas referencias a la piedad personal de sus antecesores castellanos ${ }^{210}$.

Fernando asistía a misa a primera hora de la mañana, pues se levantaba a la seis, y antes de las ocho había escuchado dos misas, al menos en $1505^{211}$. Pocos años antes, su secretario Lope Conchillos le describió orando muy temprano para asistir después al oficio divino, o a la eucaristía, en una iglesia de la ciudad ${ }^{212}$. Aunque el rezo de las horas era una práctica regia más o menos

207 Nieves Baranda, Una crónica desconocida de Juan II de Aragón (Valencia, 1541), en Dicenda: Cuadernos de filología bispánica, 7 (1988), p. 276.

208 DA BISTICCI, Le vite... [ver. n. 83], pp. 210-213. La frase entrecomillada figura en las cuentas de 1460; Gual Camarena, Servidores del infante... [ver n. 80], p. 271.

${ }^{209}$ Historia de los hechos... [ver n. 33], p. 156.

210 NiETO SORIA, Iglesia y génesis... [ver n. 13], pp. 239 y ss. Y el artículo de César Olivera sobre la religiosidad de Catalina de Lancaster, apenas reflejada en las crónicas.

211 GAIRDNER (ed.), Memorials of Henry VII... [ver n. 69], p. 250.

212 «Ayer su alteza se levantó bien de mañana y después de haver rezado, fuesse a la yglesia y estuvo en todo el officio. Después de comer durmió un poco, leyendo. Como suele, fue su altesa a caça, y mató dos milanos. Esta mañana hovo su altesa missa, y en la yglesia como suele. Después de comer, hovo música de biuela. Después fue a vísperas. Su altesa está muy bueno gracias a nuestro Señor»; carta de Lope de Conchillos a Miguel Pérez de Almazán, Ronda 12 abril 1501; Real Academia de la Historia (Madrid), Colección Salazar y Castro, A-11, f. 301 rv. 
consolidada $^{213}$, no lo era el descuido de toda forma de aparato o de seguridad de la que el rey prescindía entonces, pues «se va a missa y a vísperas como qualquyer vezino de aquí, y muchos dicen devría traher su alteza más recuado sobre sí a causa de los tornadizos [conversos]». Sin embargo, el secretario confiaba en la asistencia divina, afirmando «que puede dezir su alteza si deus est mecum quis contra me $[\mathrm{Rm} 8,31]$, plegue a su santa clemencia guardar a su alteza por muchos años». Marineo Sículo también testimonia su prioridad eucarística al comentar que «jamás comía, aunque fuese de camino, sin haber primero oído misa $»^{214}$. Y una vez sentado a la mesa «siempre un perlado, o sacerdote, bendecía su mesa y daba gracias a Dios después de comer y cenar». El ágape regio se trataba de hecho en una ceremonia de recepción donde «todos pueden pedir audiencia y verlo» ${ }^{215}$. Finalmente, tras descansar con la lectura, la caza de aves o la música de vihuela, Fernando asistía al rezo de las Vísperas.

Los ciclos litúrgicos más celebrados en la corte de Isabel y Fernando eran el de Navidad y de Semana Santa. Algunas crónicas describen el interés del monarca por preparar estas solemnidades, como en 1474, en que se detuvo en Almazán «para dar tiempo a que se le reuniese la numerosa servidumbre que le seguía y poder así celebrar más solemnemente la fiesta de Navidad» ${ }^{216}$. Los festejos navideños incluían a veces la organización de juegos caballerescos como en 1486, en que «nuestro rey poderoso / por onrar la fiesta quiso justas» ${ }^{217}$. Y el día de la Epifanía los monarcas ofrecían una significativa limosna que los identificaba con los Reyes Magos que adoran al Niño, como sucede en algunas representaciones iconográficas fernandinas con las vestes de uno de los sabios orientales ${ }^{218}$.

El esplendor de las celebraciones pascuales explica la permanencia del rey en una ciudad, donde se levantaban suntuosas capillas y se confeccionaba el locus reservationis o «monumento» para exponer al Santísimo la noche del Jueves Santo. Las cuentas reflejan la riqueza que revestía este escenario, elaborado con

${ }^{213}$ Las crónicas consignan la devoción de Fernando I de Antequera por las Horas de la Virgen, y otros testimonios describen a Enrique IV rezando las horas en su sitial del coro de la catedral de Segovia, manteniendo unas mínimas expresiones de acatamiento por parte de los canónigos; COLMENARES, Historia de la insigne ciudad... [ver n. 91], vol. II, p. 288.

214 MARINEO Sículo, Vida y hechos... [ver n. 34], p. 153.

215 Sobre el banquete regio en tiempos de los Reyes Católicos cfr. FERnándEZ DE CóRdova, La Corte de Isabel I... [ver n. 140], pp. 245-260.

216 PALENCIA, Crónica de Enrique IV... [ver n. 140], vol. II, p. 163.

217 CÁTEDRA, La historiografía en verso en la época... [ver n. 40], pp. 302-303.

218 Véanse los ejemplos proporcionados por MORTE GARCÍA, La imagen de Fernando el Católico... [ver n. 3], pp. 131 y ss. Carlos José HeRnANDo SánCHEZ, El reino de Nápoles en el Imperio de Carlos V. La consolidación de la conquista, Madrid, 2001, pp. 35-36. 
obras de carpintería y dotado desde 1486 del permiso papal de lucrar indulgencia a todos los que lo visitaran ${ }^{219}$. En 1482, en Pontón de don Gonzalo (Córdoba), Fernando «mandó armar allí su tienda», para celebrar la misa in cena Domini y exponer el Monumento ${ }^{220}$. Pero la arquitectura más sofisticada fue la «yglesia de madera toda muy adornada de ricos pannos» erigida en el real de la Peña de los Enamorados (Antequera) en 1487, para alojar el Cuerpo de Cristo transportado bajo palio y custodiado por centinelas ${ }^{221}$.

Entre las solemnidades litúrgicas anuales revistó particular importancia el Corpus Christi, que venían imponiéndose como fiesta más importante de la presencia real de Jesucristo en las especies sacramentales. Los reyes hicieron coincidir su celebración móvil con su recibimiento en algunas ciudades, como en Sevilla (1477) o en Valencia (1481) ${ }^{222}$, buscando sinergias simbólicas en un acto que se fue despojando de los carros y entremeses que distorsionaba su sentido religioso, o abaratando unos gastos que se concentrarían en los recibimientos reales, como sucedió en Zaragoza (1492) ${ }^{223}$. Fernando le dotó de particular solemnidad en la frontera de Granada, como se comprueba en la celebración de Ronda (1485) ${ }^{224}$, y se implicó personalmente portando las varas del palio con su esposa en la celebración zaragozana de 1498, buscando una proximidad física al Santísimo Sacramento, que lo convertía en privilegiado servidor de la divinidad ${ }^{225}$.

Las ceremonias políticas también tuvieron su propia dimensión religiosa: especialmente los recibimientos reales en las ciudades. En sus primeros años Fernando recibió invocaciones -semejantes a las laudes regiae- que celebraban su llegada o partida de determinados enclaves urbanos. Con motivo de su entrada en Barcelona (1472) debió componerse el poema Bien venga laltesa del muy prosperado ${ }^{226}$, y a su partida de Valladolid contra el enemigo portugués (1475) muchos niños le recibieron en la iglesia «dando vozes, que Dios diese vitoria al Rey» usando textos escriturísticos sobre el compromiso del soberano con el bien

219 Cfr. NOGALES RinCón, La representación religiosa ... [ver n. 13], p. 691.

220 MARINEO Sículo, Vida y hechos... [ver n. 34], p. 109.

${ }^{221}$ Historia de los hechos... [ver n. 33], p. 264. PUlgar, Crónica ... [ver n. 23], vol. II, p. 261.

222 CARRASCO MANCHADO, Isabel I de Castilla ... [ver n. 17], pp. 296-312.

223 Sobre este fenómeno detectado especialmente en la Corona de Aragón cfr. Alvaro ALONSO MIGUEL, El teatro en la época de los Reyes Católicos, en Nicasio SALvador Miguel, y Cristina MOYA GARCÍA (coords.) La literatura en la época de los Reyes Católicos, Madrid, 2008, p. 12. FERNÁNDEZ DE CóRDOVA, La Corte de Isabel I... [ver n. 140], pp 309 y ss.

224 Andrés Bernáldez, Memorias del reinado de los Reyes Católicos, Madrid, 1962, pp. 162-163.

225 ZURITA, Historia del rey don Hernando... [ver n. 108], libro III, cap. XXIV.

226 Duran Grau, y ReQuesens, Profecia i poder... [ver n. 15], pp. 311-324. 
común, y al final «toda la gente dieron todos grandes vozes al cielo, que Dios lo ayudase e la su bendita Madre e le diese vitoria contra sus enemigos»227.

La procesión hacia el templo era uno de los elementos más relevantes de los recibimientos reales, que culminaban con la oración del monarca ante el altar mayor tras la recepción del clero. En su entrada segoviana, coincidente con su acceso al trono (1474), Fernando fue escoltado «triunfosamente» por un cortejo de antorchas hasta la catedral, para ofrecer las «oraciones que por tales mercedes a Dios se deuen hazer ${ }^{228}$; y al año siguiente en Valladolid fue acompañado por pajes portando la inscripción Dominus michi adjutor, aludiendo a la protección divina ante el enemigo portugués. Los elementos sacralizadores aumentaron aquel día con el recibimiento del clero con el Corpus Christi y su posterior acompañamiento a cruz alzada hasta la plaza de San Francisco, contraviniendo la prohibición de Juan I de sacar del templo estos instrumentos religiosos ${ }^{229}$. En la Corona de Aragón, el clero no solía adelantarse tanto, recibiendo a los reyes a la entrada de la iglesia, donde éstos se apeaban para adorar la cruz como sucedió en Zaragoza (1486), o venerar la Vera Cruz en Barcelona (1481), el Lignum Crucis en Valencia (1481), o las reliquias presentadas por el abad de Poblet (1493) antes de recibir el palio que les acompañaría hasta la iglesia con el canto del Te Deum ${ }^{230}$. Eran los equilibrios simbólicos para prestigiar la faceta devocional de los reyes, en el marco de una teología política que los convertía en servidores privilegiados de la divinidad.

La oración ante el altar suponía un momento ineludible del recibimiento, como muestran instrucciones reales a las autoridades segovianas ordenando que «los príncipes [Felipe y Juana] se apeen a hazer oración como acostumbran los reyes» $(1502)^{231}$. La plegaria regia solía adoptar la forma de preces litúrgicas dirigidas por la autoridad eclesiástica que terminaba otorgándoles su bendición, como sucedió en Córdoba (1487) o en Poblet (1493) 232 ; y algunas ocasiones se

227 Bachiller Palma, Divina retribución sobre la caída de España en tiempo del Rey Don fuan el primero, ed. por J. M. Escudero de la Peña, Madrid, 1879, pp. 33-34.

${ }_{228}$ PUYOL (ed.), Crónica incompleta... [ver. n. 108], p. 133.

229 Cortes de Bribiesca: celebradas en el año de 1387 por Fuan I, Madrid, 1826.

230 Salvador CARRERES ZACARÉS, Ensayo de una bibliografía de libros de fiestas celebradas en Valencia y su antiguo reino, vol. I, Valencia, 1922, p. 92. Ángel SAN VICENTE PINO, El Rey nuestro senyor se venía en aqueste regno et ciutat, en Un año en la historia de Aragón, 1492, Zaragoza, 1992, p. 468. FINESTRES Y DE MONSALVO, Historia del Real Monasterio... [ver n. 50], vol. IV, p. 76.

${ }^{231}$ Colmenares, Historia de la insigne ciudad... [ver n. 91], vol. II, p. 424.

$232 \mathrm{Al}$ llegar el rey a Córdoba, se juntó su comitiva con la del príncipe que salía a recibirle, y se dirigieron a la iglesia mayor, donde «fizieron oraçión ante el altar mayor, e resçibieron la bendiçión del perlado»; PULGAR, Crónica... [ver n. 23], vol. II, p. 336. 
desplegaron sofisticadas paraliturgias, como el misterio zaragozano del Espíritu Santo celebrado en la Seo con motivo de la entrada regia de 1486 y $1498^{233}$. Desde el punto de vista político, interesa señalar la posibilidad de que se jurasen en el templo los privilegios de la ciudad ante las reliquias -y no en sus puertas-, como se desprende del relato de su entrada en Teruel (1482), donde fueron recibidos bajo palio y «llegaron a la iglesia de Santa María y allí adoradas la relicas, juró su Magestat fueros, previlegios y libertades, forma solita ${ }^{234}$. Con ello se realzaba el valor sagrado del juramento, presentándose los reyes como adoradores de Cristo al entrar en la ciudad aragonesa en vísperas de la Epifanía.

Sea como fuere, la plegaria del rey exigía un marco escénico especial para realzar su dimensión mística, lo que llevó a crear sitiales específicos, adornados con las armas o las efigies de los reyes, en algunos templos especialmente afines, como la iglesia Santo Tomás de Ávila, o las catedrales de Sevilla y Plasencia ${ }^{235}$. Los servidores de la capilla se ocupaban de crear este espacio con muebles, adornos y ornamentos necesarios que debían facilitar y enmarcar al soberano en este momento de especial relación con Dios. En la ceremonia de Valladolid de 1474, Fernando se «fincó de hinojos» en una cama de estado, mientras se recitaron oraciones implorando la asistencia divina ${ }^{236}$. El uso de este mueble regio, usado por Isabel en la recepción de la embajada borgoñona (1472-73), pretendía resaltar la condición regia del orante en aquel espacio sagrado en un momento particularmente crítico del conflicto sucesorio. Años más tarde, los monarcas prescindieron de este mueble en los actos litúrgicos, prefiriendo delimitar y dignificar su posición mediante un sitial sobrelevado, cerrado con cortinas, y suntuosamente ornamentado con cojines, alfombras y tapices, que solía colocarse a los lados del altar mayor, fuera del presbiterio ${ }^{237}$.

Una de sus primeras menciones aparece en la celebración de la victoria de Toro, donde los reyes ocuparon sendos sitiales ubicados en los extremos del altar

233 Pedro Calahorra Martínez, Entremeses y paraliturgias en La Seo zaragozana ante la presencia de los Reyes Católicos, en Nassarre: Revista aragonesa de musicología, 9/2 (1993), pp. 119-125.

${ }^{234}$ Crónicas de los jueces de Teruel (1176-1532), ed. por Fernando López Rajadel, Teruel, 1994, p. 290.

235 Pelayo Quintero ATAuri, Sillerías de coro en las iglesias españolas, Cádiz, 1928, pp. 41-42, 58 y 72. Dorothy KRAUS, y Henry KRAUS, Las sillerías góticas españolas, Madrid, 1984, pp. 164-165.

${ }^{236}$ Palma, Divina retribución... [ver n. 227], pp. 33-34. Sobre el valor simbólico de la cama de estado cfr. Álvaro FERNÁNDEZ DE CÓRDOVA MIRALles, Los símbolos del poder real, en Alberto BARTOLOMÉ y Carlos J. HeRnando (dirs.), Los Reyes Católicos y Granada, Granada, 2005, p. 54.

237 Sobre el uso de las cortinas reales cfr. ibid., p. 45. Su evolución moderna en Jorge FERNÁNDEZSANTOS ORTIZ-IRIBAS, Ostensio regis: la «Real Cortina» como espacio y manifestación del poder soberano de los Austrias españoles, en Potestas: Religión, poder y monarquía, 4 (2011), pp. 167-210. 
de la catedral toledana, sobre estrados elevados y «aparato real de cortinas de brocado» (1477). Doce años después volvemos a encontrar las cortinas reales en la capilla del castillo de la Mota durante la misa celebrada en honor de los embajadores ingleses (1489), a la que asistieron los reyes «sentados ante la cortina», elaborada con «un rico tejido de oro» ${ }^{238}$. Los infantes compartían este honor regio, permaneciendo el príncipe Juan en el sitial del rey, y las infantas en el de la reina ${ }^{239}$. A esta semiología del espacio obedecían ciertas estrategias de distinción para privilegiar a determinados cortesanos permitiéndoles una mayor proximidad a la cortina real ${ }^{240}$. Se configuraba así una singular escenificación que sorprendió a los embajadores venecianos en 1507, cuando describieron la capilla «molto excelente» con que Fernando asistió a misa en las vistas de Savona, ocupando un lujoso sitial («scabelo») con reclinatorio «coperto de sopra de pano soprarizo d'oro» que llegaba hasta el suelo, mientras los barones y caballeros permanecían en pié «tuti in línea segondo i gradi soi» ${ }^{241}$.

El rey no sólo exhibió el esplendor de su capilla en el interior de los templos. Los cronistas también documentan su disposición en lujosas cubiertas o entoldados durante la campaña de Granada. Durante el cerco de Málaga (1487), por ejemplo, las tiendas del oratorio real ocuparon el centro de una constelación de capillas repartidas por el campamento para facilitar la participación litúrgica de las tropas, mientras «muchos clérigos e frailes de todas órdenes [...] decían misas e predicavan por todo el real [...] E allende de los clérigos, havía cantores de la capilla del rey e la reina e de otras capillas de grandes; que así era honrrado el culto divino en aquel real como en una muy gran cibdad [...] con infinitas músicas e cantores ${ }^{242}$. Colorida descripción que muestra la actividad litúrgica y pastoral de aquella ciudad castrense, que parece reproducir en miniatura las sinergias religiosas entre la corte y el reino.

Junto a la celebración eucarística, Fernando cultivó el rezo de las Horas canónicas, práctica devocional que ofrecía a los laicos una selección de determi-

${ }^{238}$ Juan Manuel Bello León, y Beatriz Hernández PÉREZ, Una embajada inglesa a la corte de los Reyes Católicos y su descripción en el «Diario» de Roger Machado. Año 1489, en En la España Medieval, 26 (2003), p. 190.

239 Finestres y de MONSALVO, Historia del Real Monasterio... [ver n. 50], vol. IV, p. 77.

${ }^{240}$ Véase el privilegio concedido a los marqueses de Moya de situarse en la misa del día de Navidad «junto a la cortina real»; Alfonso FRANCO SILVA, El Condado de Chinchón. Los problemas internos de un señorío en tierras de Segovia (1480-1555), en Estudios de Historia y Arqueología Medievales, 10 (1996), p. 134.

241 SANUdO, Diarii [ver n. 60], vol. VII, col. 88.

242 Andrés BernáldeZ, Memorias del reinado de los Reyes Católicos, Madrid, 1962, p. 199. 
nados pasajes de la Escritura y de los Padres para enriquecer su vida espiritual ${ }^{243}$. Así lo muestran los testimonios aludidos que le describen asistiendo a todo el oficio divino, o los libros de Horas conservados en su biblioteca. Fernando estuvo detrás de algunos ejemplares magníficos, como el de la Biblioteca del Palacio Real -extremadamente rico en ilustraciones- que perteneció a su madre Juana Enríquez y debió regalar a su esposa ${ }^{244}$. Algo más tardío es el Libro de Horas y Misal conservado en la Biblioteca Vaticana (BAV, Chigi. C.VII.205) que su capellán mayor, el prelado napolitano Giovanni Maria Poderico, debió ofrecerle durante su estancia en Nápoles (1506-1507), con representaciones del monarca como nuevo Augusto que inaugura un nuevo período de paz gracias a su reciente alianza con Francia y el fin del conflicto napolitano ${ }^{245}$. Más allá de su sofisticado programa iconográfico, tenía su utilidad práctica como libro de viaje que permitía tanto la oración privada del oficio como la celebración pública de la misa. Finalmente contamos con el Libro de Horas atribuido al taller de Pedro Machuca (c. 1512-1514) que cuenta con cuatro miniaturas representando al monarca anciano, en posición orante, contemplando algunas escenas sagradas y también como rey penitente, desnudo con un flagelo para pedir perdón por sus pecados ${ }^{246}$.

En su biblioteca Fernando conservaba algunos ejemplares para determinados tiempos litúrgicos, como aquel «libro de papel que se llama las Oras de la Semana Santa» y alimentaría su piedad en estos días tan intensamente vividos en su corte. Sin embargo, es mayoritaria la presencia de Breviarios -el doble de los contabilizados en la biblioteca de Enrique IV- que, a diferencia de los Libros de Horas, contenían todos los textos destinados al orden eclesiástico ${ }^{247}$. Como señala Elisa Ruiz, esta práctica, documentada igualmente en el caso de la reina, suponía la apropiación de un material eucológico utilizado por clérigos que revela el interés por saltarse los límites estamentales para enriquecer la espiritualidad regia ${ }^{248}$.

Junto a los libros de horas, la biblioteca fernandina de 1510 es especialmente rica en misales, alguno con su divisa del yugo, combinado a veces con las

243 M. Jesús, LÓPEZ MonTILla, El Libro de Horas. Un libro selecto de devoción privada, Madrid, 2012.

${ }^{244}$ Matilde Lopez SERrano (ed.), El libro de horas de Isabel la Católica, Madrid, 1969.

${ }^{245}$ M. Carmen Morte GarCía, El Maestro del Misal-Breviario vaticano de Fernando el Católico, en Boletín del Museo e Instituto Camón Aznar, 89 (2002), pp. 261-286. Y el citado trabajo de Tess Knighton.

246 MORTE García, El viaje de los príncipes... [ver n. 187], pp. 63-65.

${ }^{247}$ Los ejemplares enriqueños en Miguel Ángel LADERO QUESADA, Capilla joyas y armas, tapices y libros de Enrique IV de Castilla, en Acta bistorica et archaeologica mediaevalia, 26 (2005), p. 859.

248 Elisa RUIZ GarCía, Los Breviarios de la Reina Católica: un signo de modernidad, en III Fornadas científicas sobre documentación en tiempos de los Reyes Católicos, Madrid, 2004, pp. 221-248. 
flechas ${ }^{249}$. Más difíciles de identificar son los «libros de rezo», algunos bastante lujosos y con aparato iconográfico, de acuerdo a las nuevas corrientes espirituales que defendían el uso de las imágenes para aumentar el valor empático con el texto y facilitar la contemplación mística de las escenas ${ }^{250}$. Es el caso del «libro de rezos de mano, de pergamino con algunas ymaginerías, cubierto de terciopelo negro con dos corchetes y dos camafeos en ellos»; «otro libro de rezar de pargamino, de mano, con algunas ymaginerías, cubierto de damasco con dos corchetes de plata»; o aquel «libro de rezar de pargamino, scrito de mano, cubierto de terciopelo negro con sus corchetes, y enbras de plata doradas» ${ }^{251}$.

\section{b) Sintonías inmaculistas a la sombra del Precursor}

Junto a los misterios cristológicos, Fernando manifestó una devoción particular a la Virgen, por probable influencia de su padre, de quien heredó su afiliación a la Hermandad del Pilar ${ }^{252}$ y ciertas piezas de devoción, como el suntuoso tapiz sobre los siete gozos de la Virgen ${ }^{253}$. Durante el reinado visitó diversos santuarios marianos, se rodeó de una capilla musical dotada de un importante repertorio mariológico, y se interesó por celebrar las fiestas de la Madre de Dios, como hizo al visitar el Santuario de Guadalupe el 8 septiembre de 1483 para celebrar su Natividad ${ }^{254}$. Fernando recurrió a «su gloriosa madre nuestra señora, la Virgen María» como principal intercesora en su testamento de 1475, y atribuyó a su protección en el atentado de Barcelona (1492), peregrinando en acción de gracias a Monserrat con el resto de su familiaa ${ }^{255}$. Durante la guerra de Granada se hizo representar repetidas veces ante la Virgen, junto a su esposa y los infantes, y no faltan referencias a hechos milagrosos como la visión de María con una palma

249 RAH, Colección Salazar y Castro, M-198, ff. 91v y 104v.

250 Olga PÉreZ MonZón, Imágenes sagradas. Imágenes sacralizadas. Antropología y devoción en la Baja Edad Media, en Hispania sacra, 64/130 (2012), pp. 449-495.

251 RAH, Colección Salazar y Castro, M-198, ff. 139v-140r.

252 Sobre la devoción fernandina a la Virgen del Pilar y sus manifestaciones de mecenazgo en la Basílica cfr. MORTE GARCÍA, El viaje de los príncipes... [ver n. 187], pp. 67-68.

253 Jaime ViCENS VIVES, Jaime, Juan II de Aragón (1398-1479). Monarquía y revolución en la España del siglo XV , Barcelona, 1953, pp. 183 y ss. Miguel Ángel ZaLAMA RoDRíGUEZ, y Jesús Félix PASCUal Molina, Tapices de fuan II de Aragón y Fernando el Católico en La Seo de Zaragoza, en Boletín del Museo e Instituto Camón Aznar, 109 (2012), pp. 293 y ss.

254 Palencia, Guerra de Granada... [ver n. 29], p. 63. KNIGHTON, Música y músicos... [ver n. 71], pp. $135-140$.

255 Véanse las referencias de Teresa Jiménez Calvente. 
de la victoria en el cerco de Málaga ${ }^{256}$. Años más tarde, en el conflicto con Francia, la lírica palatina volvió a vehicular la intercesión mariana para que dé «favor a nuestro rey, / que os sirve con mucha ley / y os tiene por su consuelo» ${ }^{257}$.

En el terreno devocional es especialmente elocuente la portada del monasterio de Santa Engracia, donde el rey se hizo representar orante ante la Virgen con un rosario de cuentas entre las manos (c. 1514-1517). El «salterio de la Virgen» era una devoción difundida por la orden dominica -tan afín a Fernando-, que durante su reinado recibió el neologismo rosario y adquirió su forma actual -estructurado en cinco decenas y tres series de misterios- para contemplar los principales episodios de la vida de Jesús y de María ${ }^{258}$. Con su emblemática representación de Santa Engracia, Fernando no sólo difundía esta práctica junto a su esposa, sino que se convertía en uno de los primeros monarcas en esgrimir su instrumento como insignia devocional ${ }^{259}$.

Fernando también se sumó a la corriente favorable a la Inmaculada Concepción, reactivada a fines del siglo XV. Debió influir la afinidad inmaculista de su padre Juan II, sus contactos con el lulismo y el franciscanismo favorables al dogma, o su protección a la orden Concepcionista ${ }^{260}$. El monarca no sólo celebró en su corte la fiesta de la Inmaculada y la incluyó entre las que debían celebrarse en Cataluña (1503) ${ }^{261}$, sino que fundó el Hospital y Cofradía Real de la Concepción de la Corte que más adelante comentaremos. Con todo, los monarcas no se

256 Pulgar, Crónica... [ver n. 23], vol. II, pp. 316. Marion REDER GADOW, La devoción a la Virgen de la Victoria de Málaga durante los tiempos modernos, en Valeriano SánCHEZ RAMOs (dir.), Los mínimos en Andalucía, Almería, 2006, pp. 389-410.

257 José Romeu Figueras, Cancionero Musical de Palacio (Siglos XV-XVI), vol. IV-2, Barcelona, 1965, pp. 324-325.

${ }^{258}$ No es casualidad de las primeras cofradías del rosario surjan durante el reinado, fundándose en los conventos dominicos de Sevilla, Málaga o Granada tras la conquista, donde se dice que ingresaron los reyes y el arzobispo Hernando de Talavera; Carlos José ROMERO MENSAQUE, El rosario y sus cofradías en Andalucía: una aproximación histórica, en Hispania sacra, 62/126 (2010), pp. 621-659. Véase también Antonio de la TORRE Y DEL CERRO, Testamentaría de Isabel la Católica, Valladolid, 1968, pp. 21, 266, 268, 269 y 427. Francisco B. MARCOS ÁLVAREZ, «Lágrimas de Moisén»: un fitónimo en el «Libro de Buen Amor»: sus valores e implicaciones textuales y su probable origen, en Actas del III Congreso Internacional de Historia de la Lengua Española, vol. II, Madrid, 1996, pp. 1407-1409.

259 Aunque son conocidas las representaciones de algunas reinas sosteniendo un rosario, no tengo constancia de que existan ejemplos semejantes para los monarcas Trastámara; cfr. NOGALES RINCÓN, La representación religiosa.... [ver n. 13], p. 457.

${ }^{260}$ Nieves BARANDA, Una crónica desconocida de Juan II de Aragón (Valencia, 1541), en Dicenda: Cuadernos de filología hispánica, 7 (1988), p. 276. COLMENARES, Historia de la insigne... [ver n. 91], vol. II, p. 376. María MATESANZ DEL BARRIO, El Breviario de la Inmaculada Concepción y Ambrosio Montesino. Una noticia bibliográfica, en Revista de Filología Románica, 14 (1997), pp. 273-281.

261 Suzanne Straton, La Inmaculada Concepción en el arte español, Madrid, 1989, p. 11. 
decantaron oficialmente en el crispado ambiente que enfrentaba a franciscanos y dominicos, recibiendo de un «servidor» de ésta última orden el inédito Tratado sobre la materia de la conceptión y santificatión de la Virgen María que les exhortaba a permitir un sereno debate sobre la Concepción Inmaculada, tal vez al calor de las agresivas disputas de Valladolid (1502) ${ }^{262}$.

Próximo a la devoción mariana se haya la predilección fernandina por San Juan Bautista, mientras su esposa se inclinaba por el Evangelista, articulando una relación binaria -no exclusiva- de los santos Juanes con ambos reyes ${ }^{263}$. Esta simetría devocional debió suscitarse a inicios del reinado junto a la distribución emblemática (el yugo fernandino y las flechas isabelinas), asociando en numerosas representaciones iconográficas a los monarcas con su santo respectivo ${ }^{264}$. Curiosamente la figura del Bautista se hallaba más difundida en la Corona de Aragón ${ }^{265}$, y el propio Juan II atesoraba joyas con representaciones suyas ${ }^{266}$. Sea como fuere, en el testamento de 1475 Fernando citaba como primer intercesor al «bienaventurado Sant Juan Baptista [...] en quien yo tengo especial devoción» ${ }^{267}$.

San Juan compartía con el príncipe aragonés un nacimiento milagroso, y como último de los profetas podía sintonizar con los vaticinios fernandinos sobre el triunfo de la fe y la unidad de los cristianos. Su vida áspera como eremita debió establecer vínculos caballerescos con el rey, que se adivinan en su

262 Biblioteca de Catalunya (Barcelona), Ms. 2018; cfr. Pedro Manuel CATEDRA, Lectura, polifonía y género en la Celestina y su entorno, en Gonzalo SANTONJa (coord.), Celestina. La comedia de Calisto y Melibea, locos enamorados, Madrid, 2001, pp. 33-58.

263 No conviene por ello llevar demasiado lejos la rivalidad hagiográfica de los santos Juanes en lo que respecta al matrimonio real, pues Isabel cita al Bautista en su testamento y Fernando al Evangelista; cfr. Jesús MENÉNDEZ PELÁEZ, Rivalidad hagiográfica en la literatura española medieval y renacentista: los dos Santos Fuanes, en Studium Ovetense, 29 (2001), pp. 315-345. Andrew M. BERESFORD, Saints Fohn the Baptist and Fohn the Evangelist in the Cancionero of Juan de Luzón, en Alan DeYERMOND, y Barry TAYLOR (eds.), From the «Cancionero da Vaticana» to the «Cancionero general»: Studies in Honour of fane Whetnall, Londres, 2007, pp. 75-88.

264 Esta asignación devocional se documenta al menos desde 1478; Alonso de PALENCIA, Cuarta década, ed. por José López de Toro, Madrid, 1970-74, p. 25. Entre las representaciones iconográficas cabe recordar la tabla donada por los Reyes Católicos a la catedral de Málaga en honor a San Juan Bautista, la portada del convento de Santa Cruz la Real de Segovia, la Piedad de san Juan de los Reyes de Granada, o el retablo proyectado por Juan Guas para San Juan de los Reyes de Toledo.

265 María Jesús GÓMEZ BÁRCENA, La devoción a fuan el Bautista y su proyección en los retablos: aportaciones a la modalidad esculpida tardogótica, en Imágenes y promotores en el arte medieval: miscelánea en bomenaje a foaquín Yarza Luaces, Barcelona, 2001, pp. 407-422.

${ }^{266} \mathrm{El}$ rey poseía una lujosa cadena que llevaba a ambos lados una imagen de la Virgen y otra del Bautista; Jesús Félix PASCUAL MOLINA, Fuan II y las artes suntuarias, en Ars longa: cuadernos de arte, 24 (2015), p. 77.

267 BERWICK Y DE ALBA, Noticias históricas... [ver n. 104], p. 233. 
irrupción por el Ampurdán, en «la fiesta de San Juan Bautista», para liberar a su padre sitiado en Perpiñán (1473), y otras acciones militares como la «impetuosa salida el día de San Juan» en el cerco de Baza (1489) ${ }^{268}$. En las representaciones plásticas, sus rasgos de anacoreta (túnica de piel de camello, macilento y descarnado) apuntalaban la austeridad del monarca, arrodillado junto a él en un suntuoso marco cortesano ${ }^{269}$. Talavera debió animar su devoción a este «digno boz e idóneo luxero y pregonero de aquel excellentísimo Verbo», como le denomina en su Tratado de loores de San fuan Evangelista (c. 1476) dedicado a su esposa ${ }^{270} ;$ y años después su predicador Ambrosio Montesino escribió las coplas A reverencia de Sant fuan Baptista (c. 1486-1508) «por mandado del rey Fernando nuestro señor $[\ldots]$ soberano [...] más clemente, más cristiano» que como «siervo» del Precursor encontraría en él «la sabiduría / que en san Juan [Evangelista] mejor se aguza» ${ }^{271}$.

La memoria del santo se detecta en el cuidado de sus reliquias conservadas en las colecciones reales, como la «cabeça de Sant Juan Bautista» ${ }^{272}$, o el brazo y mano del Precursor que fueron depositadas en la capilla de Granada en un lujoso relicario de los Reyes Católicos ${ }^{273}$. La capilla musical fernandina también celebraba su fiesta (24 junio) con composiciones específicas, como Tibi Christe splendor ${ }^{274}$; y en 1504 puso bajo su advocación la Capilla Real de Granada, donde dispuso su enterramiento junto a su esposa, con la que compartía esta devoción ${ }^{275}$. Fernando debió trasmitírsela a su primogénito Juan, nacido seis días después de su fiesta (1478) e investido caballero por el rey en su víspera $(1490)^{276}$. Ambos se hicieron representar junto al Bautista en el retrato que se conservaba en la capilla de Granada, y la efigie del Precursor adorna uno de los dos medallones del sepulcro del

268 PALENCIA, Crónica de Enrique IV... [ver n. 140], vol. III, p. 153. ID., Guerra de Granada... [ver n. 29], p. 260.

269 Michel Pastoureau, Guía iconográfica de la Biblia y los Santos, Madrid, 1996, pp. 226-228.

270 Véase el interesante estudio de Carmen PARRILla (ed.), Hernando de Talavera, Dos escritos destinados a la reina Isabel, Valencia, 2014.

${ }^{271}$ Coplas a reverencia de Sant Juan Baptista y del misterio de la santa visitación que la reina hizo a santa Isabel, las quales compuso por mandado del rey Fernando, nuestro Señor; MONTESINO, Cancionero... [ver n. 124], pp. 77-93. No fue la única obra del predicador en honor al Bautista, pues también compuso las coplas musicalizadas Del descabeçamiento de Sant fuan Baptista, quizá para equilibrar los tres poemas dedicados al Evangelista por mandato de la reina y sus damas; SALVADOR MigUEL, Fernando el Católico y la literatura... [ver n. 73], p. 83.

272 TORRE Y DEL CERRO, Testamentaría... [ver n. 258], p. 255.

273 Antonio Gallego y Burín, La Capilla Real de Granada, Madrid, 1931, pp. 105-106.

274 KNIGHTON, Música y músicos... [ver n. 71], p. 129.

275 NOGALES RiNCÓN, La representación religiosa... [ver n. 13], p. 1756.

${ }^{276}$ Véanse los testimonios de Fernando del Pulgar, Juan Barba y el bachiller Palma. 
príncipe en Santo Tomás de Ávila (c. 1512)277. Con ello se estaba transformando el santo protector del rey en un santo dinástico.

Fernando también recurrió a la intercesión del apóstol Santiago en su testamento de 1475, y le invocó durante la guerra con Portugal buscando un referente religioso para oponerse al invasor portugués ${ }^{278}$. Después, los monarcas encomendaron al Apóstol el éxito de la guerra de Granada, acudieron a venerar sus restos en Compostela, advirtieron su intervención milagrosa en el asedio de Cambril ${ }^{279}$, y titularon con su advocación -junto con la de san Juan- 9 de cada 10 iglesias fundadas en el reino conquistado ${ }^{280}$. Los reyes también celebraron las ceremonias de acción de gracias en templos dedicados al santo, enarbolando su pendón junto a la cruz, o invocándole como «guía y abogado» de la empresa ${ }^{281}$. En su capilla Fernando conservaba una imagen suya, con otra de San Jorge, y en su lecho de muerte acudió a su protección llamándole «luz y espejo y Patrón de las Españas» como había hecho su predecesor Enrique IV.

Finalmente hay que comentar su creciente devoción por otro protector caballeresco: el arcángel San Miguel, que desde su intercesión en la guerra civil irá ganando posiciones especialmente en los últimos años de reinado. A su protección Fernando encomendó su nieto homónimo (1498-1500), primogénito de Isabel de Portugal, que heredaría los reinos hispanos bajo el apelativo de «Miguel de la Paz». El arcángel es el intercesor más representado en el inventario de 1510, recibió sus propios himnos en la capilla fernandina, y «usurpó» la primera posición que ostentaba San Juan como intercesor, en su testamento de 1516 que lo invoca como «glorioso archángel San Miguel» ${ }^{282}$.

\section{c) El circuito de la charitas entre la corte y el reino}

Junto a la dimensión litúrgica y devocional, la corte fernandina desplegó una actividad asistencial de perfiles cambiantes, que hunde sus raíces en la cha-

277 Joaquín YARZA LUACES, El tesoro sagrado de Isabel la Católica, en Isidro G. BANGO TORVISO (coord.), Maravillas de la España medieval: Tesoro sagrado y monarquía, vol. I, Valladolid, 2001, p. 315.

278 Carrasco Manchado, Isabel I de Castilla... [ver n. 17], p. 224.

279 PALENCIA, Guerra de Granada... [ver n. 29], pp. 133-134.

280 José Enrique LóPEZ DE CoCa CASTAÑER, El Reino de Granada (1482-1501), en ID., y Manuel GONZÁlEZ JimÉnEZ, Historia de Andalucía, vol. III, Barcelona, 1980, pp. 412-413.

${ }^{281}$ La expresión es de Carlo Verardi en Dolores RINCÓN GONZÁLEZ, «Historia Baetica» de Carlo Verardi. Drama humanístico sobre la toma de Granada, Granada, 1992, p. 309.

282 Knighton, Música y músicos... [ver n. 71], pp. 129-131. CALDERÓN ORTEGA, y DíAZ GONZÁLEZ, El proceso de redacción... [ver n. 9], p. 44. 
ritas cristiana difundida entre los laicos a fines de la Edad Media. Como es sabido, la corte generó un órgano específico, la Limosnería, que debía paliar las situaciones de menesterosidad con las que entraba en contacto la corte. Como señala Germán Gamero, Fernando mantuvo la vinculación del cargo al abad de Poblet, sirviéndose de sus delegados y los mozos de la limosnería, creando además un limosnero vinculado a la administración castellana, ostentado por Pedro de Alcaraz (c. 1470 y 1496), que multiplicó las vías de la munificencia regia.

Los cronistas ponderaron esta faceta de la personalidad regia, señalando que Fernando «preciábase de la clemencia y humanidad cerca de los afligidos y miserables» ${ }^{283}$. Uno de los momentos litúrgicos que evidenciaban esta dimensión caritativa era el lavatorio de pies que tenía lugar al comienzo del Triduo Pascual, donde el monarca lavaba los pies a doce o trece pobres, al menos desde el siglo XIII en Castilla ${ }^{284}$. Marineo Sículo advirtió la fuerza cristomimética de este gesto que identificaba al monarca con Jesucristo, al describir cómo al llegar el Jueves Santo, «imitando el ejemplo y doctrina de Cristo [Fernando] mandaba buscar doce pobres, y les lavaba los pies, y les daba de comer, sirviéndolos a la mesa, y los vestía de nuevo, y daba a cada uno un ducado de oro» ${ }^{285}$. De creer a los biógrafos de Talavera no era un gesto simbólico, sino una práctica que Fernando debió aprender de su confesor, con quien se confabulaba para animar la generosidad de sus nobles a la salida de la iglesia ${ }^{286}$.

La actividad asistencial del rey saltó a las crónicas durante la guerra de Granada al organizar un hospital castrense que otras fuentes atribuyen a su esposa ${ }^{287}$. Las descripciones remarcan el contraste del lujo palaciego que se pone al servicio de los que sufren, con la participación de cortesanos y capellanes que seguían el ejemplo regio. Se trataba de un complejo arquitectónico «fecho de ricas tiendas, en el qual traya capellanes que contino dixesen mysa e confesasen los feridos y enfermos, e físicos e çirugianos que los curasen. [...] e onbres e mugeres quantos menester eran para el servicio de todo» ${ }^{288}$. No fue un gesto sin consecuencias,

283 Marineo Sículo, Vida y hechos... [ver n. 34], p. 154. Historia de los hechos... [ver n. 33], pp. 154-155. ${ }^{284}$ NOGALES RiNCÓN, La representación religiosa... [ver n. 13], pp. 689-690.

285 MARINEO Sículo, Vida y bechos... [ver n. 34], p. 169.

286 Pedro de Alcántara refiere que en las misas celebradas por Fray Hernando en Granada, el rey «mandava echar dos ducados» como limosna a los pobres, «y así los caballeros cortesanos, siguiendo el ejemplo de su príncipe, lo hacían liberalmente; de manera que con esta diligencia se mantenía a toda aquella pobre gente en sus casas»; SUAREZ Y MUÑANO, Vida del venerable... [ver n. 93], p. 219.

287 PALENCIA, Guerra de Granada... [ver n. 29], pp. 155-156.

${ }^{288}$ Historia de los hechos... [ver n. 33], pp. 156. Véase también el sermón de 1493 que atribuye esta iniciativa a ambos reyes; Delgado SCHOll, y PEREa Rodríguez, Predicación religiosa... [ver n. 135], p. 25. A diferencia de Pulgar y Juan Barba que la adscriben a la reina. Sobre la eficacia 
pues aquella sensibilidad se trasfirió a las ciudades conquistadas con la erección de hospitales permanentes, como el de San Marcos en Vélez-Málaga (1487), mientras se desarrollaba en aquellos mismos años la Limosnería de la reina con un cuerpo jerarquizado de servidores ${ }^{289}$.

La práctica asistencial maduró en la década de 1490 con la fundación de la Cofradía u Hospital de Corte, en un ambiente influido quizá por las iniciativas humanitarias impulsada por Cisneros en aquellos años ${ }^{290}$. Esta fundación cortesana unía a una finalidad piadosa -el culto a la Inmaculada Concepción- la atención a los necesitados, que cristalizó en una institución propiamente asistencial bajo la denominación de Hospital de pobres de la Corte. Aunque formaban parte de ella «quasi todos quantos siguen nuestra corte o serviçio», estaba abierta a otros grupos, como los familiares de los oficiales, ofreciendo una plataforma caritativa más allá de los límites palatinos. Las instrucciones de 1495 a sus procuradores en Roma reflejan la voluntad de dotarla de gracias e indulgencias y una capellanía propia dentro de la Corte para la administración de los sacramentos, lo que suponía generar una institución autónoma, aunque relacionada con la Capilla, que aumentaba la posibilidad de atender mejor, o de manera independiente, las situaciones de menesterosidad con las que se encontraban los cortesanos.

Su puesta en marcha es coetánea al impulso de hospitales de la Corona de Aragón, como el valenciano erigido por la Cofradía de Nuestra Señora de los Inocentes, Mártires y Desamparados (1493-1494), cuya traza data de 1494, un año antes de que el rey añadiera el apelativo «Nostra Dona dels Desamparats» que establecía un vínculo mariano análogo al de la cofradía cortesana ${ }^{291}$. Poco después, Fernando se interesó por el Hospital de Nuestra Señora de Gracia de Zaragoza dándole nuevas ordinaciones (1496) para regular su gobierno y funcionamiento, e iniciando un proceso de absorción por parte del poder real que culminará con las ordenaciones de

del hospital de campaña cfr. Miguel Ángel LADERO QUESADA, Ejército, logística y financiación en la Guerra de Granada, en Seis lecciones sobre la Guerra de Granada, Granada, 1983, pp. 49 y ss.

289 Así lo demuestras las cuentas registradas a partir de 1486; Eloy BENITO RUANO (ed.), El libro del limosnero de Isabel la Católica, Madrid, 1989. Y los recientes trabajos sobre la labor asistencial de la reina David NOGALES RINCÓN, La asistencia social durante el reinado de los Reyes Católicos: las limosnas reales a menesterosos, en Población y grupos sociales en el Antiguo Régimen, vol. II, Málaga, 2009, pp. 1021-1038. Rosana DE ANDRÉs DÍAZ, Las caridades de Isabel la Católica (1495-1504), en Homenaje al profesor Eloy Benito Ruano, vol. I, Murcia, 2010, pp. 71-90.

290 José GARCía ORO, Cofradía y Hospital de la concepción de la Corte, en La Virgen María en la religiosidad española del siglo XVI, Salamanca, 1980, pp. 171-193. Sobre la actividad cortesana de Cisneros en aquellos años cfr. GARCÍA ORO, El Cardenal Cisneros... [ver n. 169], vol. I, pp. 92 y ss.

291 Mercedes GómEZ-FERRER LOZANO, Arquitectura en la Valencia del siglo XV. El Hospital General y sus artifices, Valencia, 1998, pp. 40 y 86-92. 
$1508^{292}$. Son los tempranos ejemplos aragoneses que prepararon los grandes hospitales erigidos a fines del reinado: el Hospital Real de Santiago (1499), el de Santa Cruz de Toledo, y el de Granada (1501-1504) ${ }^{293}$. Fundaciones regias que obedecían al propósito fernandino, recordado en su lecho de muerte, «de lo hacer por lo ofrecer a Nuestro Señor, y que los sacrificios y sufragios que en ellos se hicieren sean en alguna enmienda de nuestros pecados y culpas». Se cerraba así el círculo de una práctica asistencial alimentada por las sinergias espirituales entre la corte y el reino que unía el bienestar de los súbditos y la salvación del rey.

A la vista de estas páginas salta a la vista la versatilidad religiosa de Fernando II de Aragón, tanto en su vida personal como en su imagen pública. Ambas dimensiones resultan esenciales para comprender a un monarca tan ligado a la piedad de sus antecesores, como permeable a las nuevas corrientes religiosas -compartidas con su esposa- que estaban transformando la espiritualidad de las élites, como el humanismo cristiano -latino o vernáculo-, la teología dominica, o la espiritualidad afectiva franciscana, que buscaban un acercamiento más directo a la humanidad de Cristo -especialmente en su Pasión- a través de las fuentes escriturísticas y una interpretación del hecho salvífico ligado al presente a través de la liturgia y las nuevas formas de contemplación.

Con sus luces y sus sombras morales, sus acentos proféticos y sus expresiones devocionales, el mérito fernandino estriba en haber integrado estas corrientes y haberlas impulsado con un notable mecenazgo religioso y una piedad exterior e interior que no pasó desapercibida a sus contemporáneos. El ambiente cortesano de los Austrias fue, de hecho, heredero del clima espiritual consolidado por el último Trastámara que -como en otros aspectos del reinado- comprendió buena parte de las novedades espirituales de aquel tiempo, se adaptó a ellas y profundizó en las líneas que determinarán el futuro religioso de la Monarquía Hispánica en la Europa moderna. Detrás de esta evolución se perfila la silueta del «otro príncipe» que soñó Talavera para un hombre que estas líneas han querido reinventar.

292 Aurelio BAQUERO, Bosquejo histórico del Hospital Real y General de Nuestra Señora de Gracia de Zaragoza, Zaragoza, 1952, pp. 28-39. María Luisa DE ANDRÉS TURRIÓN, y Ignacio ANDRÉs ARRIBAS, Las Ordinaciones de Fernando el Católico del Hospital de Nuestra Señora de Gracia de Zaragoza: el oficio de especiero o boticario, en Actas del IX Congreso Nacional de Historia de la Medicina, vol. II, Zaragoza, 1991, pp. 427-432. Cristina MONTERDE AlBIAC, Las ordinaciones del Hospital de Nuestra Señora de Gracia de Zaragoza establecidas por don Alfonso de Aragón, arzobispo de Zaragoza y lugarteniente general del reino, en Aragón en la Edad Media, 20 (2008), pp. 505-528. Mercedes GALLENT MARCO, Los hospitales de la Santa Creu de Barcelona y Nuestra Señora de Gracia de Zaragoza, dos modelos asistenciales para el Hospital General de Valencia, en Aragón en la Edad Media, 25 (2014), pp. 49.

${ }^{293}$ Una panorámica general en YARZA LUACES, Los Reyes Católicos... [ver n. 47], pp. 83-85. 